Modern Asian Studies 54, 2 (2020) pp. 502-553. (C) The Author 2019. This is an Open Access article, distributed under the terms of the Creative Commons Attribution licence (http:// creativecommons.org/licenses/by/4.o/), which permits unrestricted re-use, distribution, and reproduction in any medium, provided the original work is properly cited. doi:Io.1017/Soo26749XI70oro32 First published online i6 August 2019

\title{
A Dreadful Scourge: Cholera in early nineteenth-century India*
}

\author{
MARK HARRISON \\ University of Oxford \\ Email:mark.harrison@history.ox.ac.uk
}

\begin{abstract}
In I8I7-2I, the Indian subcontinent was ravaged by a series of epidemics which marked the beginning of what has since become known as the First Cholera Pandemic. Despite their far-reaching consequences, these epidemics have received remarkably little attention and have never been considered as historical subjects in their own right. This article examines the epidemics of I8I7-2I in greater detail and assesses their significance for the social and political history of the Indian subcontinent. Additionally, it examines the meanings that were attached to the epidemics in the years running up to the first appearance of cholera in the West. In so doing, the article makes comparisons between responses to cholera in India and in other contexts, and tests the applicability of concepts used in the study of epidemics in the West. It is argued that the official reaction to cholera in India was initially ameliorative, in keeping with the East India Company's response to famines and other supposedly natural disasters. However, this view was gradually supplemented and replaced by a view of cholera as a social disease, requiring preventive action. These views were initially rejected in Britain, but found favour after cholera epidemics in $183^{\mathrm{I}-} 3^{2}$. Secondly, in contrast to later epidemics, it is argued that those of I8I7-2I did little to exacerbate tensions between rulers and the ruled. On the rare occasions when cholera did elicit a violent reaction, it tended to be intra-communal rather than anti-colonial in nature.
\end{abstract}

* The author is grateful to the European Research Council which assisted research for this article through the award of grant 34012I ('Diseases of Modern Life: NineteenthCentury Perspectives'). He is indebted to Tony K. Stewart who read an earlier version of this article and made many helpful comments and suggestions. He would also like to thank the anonymous referees for their comments and suggestions. 


\section{Introduction}

The waves of cholera that engulfed India between I8I7 and I82I marked a turning point in the history of the subcontinent and, ultimately, of much of the world. Within a year of the first epidemic, which began in the town of Jessore in what is now western Bangladesh, most of British India had experienced outbreaks of varying severity. ${ }^{1}$ By the early I820s, cholera had spread by sea and land to other Asian countries, later arriving in Africa, Europe, and the Americas. ${ }^{2}$ It defined the contours of a new world economy, revealing its connections and also, more starkly, its divisions. ${ }^{3}$ Everywhere it travelled, cholera became synonymous with poverty, squalor, and neglect. ${ }^{4}$ But in 1817 these associations were far from clear and the responses to the first all-India epidemics differed radically from those which occurred later. These unique features have gone largely unnoticed because the events of I8I7-2I have yet to be studied in depth. In existing scholarship, they appear briefly as a prologue to subsequent epidemics or are secondary to other concerns. David Arnold's pioneering study of cholera devotes only a few pages to the epidemics of I8I7-2I and draws evidence chiefly from western and central India, not from Bengal where the outbreak originated. ${ }^{5}$ Other scholars have also focused on particular regions, especially Madras, as in the case of Niels Brimnes and Michael Zeheter. ${ }^{6}$ Their work concentrates largely on urban governance (in the case

${ }^{1}$ The years I8I7-2I have come to be regarded as the first of cholera's 'epidemic phases' - a term popularized at the end of the century by Calcutta's health officer W. J. Simpson. The second of these phases occurred in $1826-37$ and the third in $1846-$ 63. See J. N. Mitra, 'Cholera', The Calcutta Medical Journal, 4, I909-10, pp. I-8.

${ }^{2}$ Robert Peckham, Epidemics in Modern Asia, Cambridge: Cambridge University Press, 2016, pp. 53-63; David Arnold, 'The Indian Ocean as a Disease Zone, I500-1950', South Asia, XIV, 2, I99I, pp. I-2I; Myron Echenberg, Africa in the Time of Cholera: A History of Epidemics from I8I7 to the Present, Cambridge: Cambridge University Press, 200I; Leonard Rogers, Cholera and its Treatment, London: Oxford University Press, I9I I, pp. II-I5.

${ }^{3}$ Mark Harrison, 'Disease and World History from 1750', in J. J. McNeill and K. Pomeranz (eds), The Cambridge World History. Volume VII: Production, Destruction, and Connection, I750-Present. Part I: Structures, Spaces, and Boundary Making, Cambridge: Cambridge University Press, 2015, pp. 237-57.

${ }^{4}$ Christopher Hamlin, Cholera: The Biography, Oxford: Oxford University Press, 2009, pp. $78-80$.

${ }^{5}$ David Arnold, Colonizing the Body: State Medicine and Epidemic Disease in Nineteenth-Century India, Berkeley: University of California Press, I993, pp. 159-63, I69-75; D. Arnold, 'Cholera and Colonialism in British India', Past and Present, II3, I986, pp. II8-5I.

${ }^{6}$ Niels Brimnes, 'Coming to Terms with the Native Practitioner: Indigenous Doctors in Colonial Service in South India, I80o-25', Indian Economic and Social History Review, 50, I, 
of Zeheter) and the employment of indigenous practitioners. The epidemics of I8I7-2I have also been examined by historians of medical theory and practice, ${ }^{7}$ the most extensive treatment appearing in Seema Alavi's monograph Islam and Healing. ${ }^{8}$

Scholarship on the first all-India cholera epidemics is therefore fragmentary. Those who have examined them have done so for different reasons and have reached rather different conclusions about their meaning and significance. Whereas Arnold sees the events of I8I7-2I as a crisis intimately connected to colonialism, others, notably Alavi and Brimnes, adduce substantial evidence of cooperation. These contrasting accounts provide tantalizing glimpses into a medical catastrophe that was probably unprecedented in the history of the subcontinent. ${ }^{9}$ This article seeks to determine how far the claims hitherto made about the epidemics of I8172I can be generalized, paying particular attention to how they affected different communities and their relationship with the colonial state. It also traces the legacy of these events for would become an imperial and, eventually, global discourse on 'Epidemic' or 'Asiatic' cholera. ${ }^{10}$

In the light of later outbreaks, one might expect those of I8I7-2I to have strained relations between the East India Company and its subjects. Following the Rebellion of 1857 , cholera elicited a powerful reaction

2013, pp. 77-Io9; Michael Zeheter, Epidemics, Empire and Environments: Cholera in Madras and Quebec City, I8I8-I9Io, Pittsburgh: University of Pittsburgh Press, 2015, Chapter I.

${ }^{7}$ Projit Bihari Mukharji, Nationalizing the Body: The Medical Market, Print and Daktari Medicine, London: Anthem Press, 2009, pp. 179-8I; Mark Harrison, Medicine in an Age of Commerce and Empire: Britain and its Tropical Colonies I660-1830, Oxford: Oxford University Press, 20го, esp. pp. 95-102; M. Harrison, Climates and Constitutions: Health, Race, Environment and British Imperialism in India I60o-I850, Delhi: Oxford University Press, I999, pp. I77-9I.

${ }^{8}$ Seema Alavi, Islam and Healing: Loss and Recovery of an Indo-Muslim Medical Tradition, I60o-I90o, Basingstoke: Palgrave Macmillan, 2008, pp. Io9-I8.

${ }^{9}$ There is no evidence that the 'Black Death' reached India during its spread in the fourteenth century. The nearest the subcontinent came to experiencing an epidemic on the scale of cholera was during the plagues of the late seventeenth century, but these were confined chiefly to northern India. See George D. Sussman, 'Was the Black Death in India and China?', Bulletin of the History of Medicine, 85, 2011, pp. 319-55; Syud Ahmud (ed.), Tuzuk-i-Jahangiri, Aligargh: Private Press, I864, pp. 209-10.

${ }^{10}$ On the circulation of opinion concerning cholera, see Projit Bihari Mukharji, 'The "Cholera Cloud" in the Nineteenth-Century "British World": History of an Object-without-an-Essence', Bulletin of the History of Medicine, 86, 3, 2013, pp. 303-32. On the 'Asiatic' aspects of cholera, see Mark Harrison, 'A Question of Locality: The Identity of Cholera in British India, I860-I89o', in D. Arnold (ed.), Warm Climates and Western Medicine, Amsterdam: Rodopi, I999, pp. I33-59. 
from the British, who imposed quarantine and sanitary cordons to protect troops and European enclaves. ${ }^{11}$ This coercive response was attenuated in subsequent outbreaks, but the military continued to insist on the use of cordons from time to time, chiefly to protect its garrisons in Punjab. ${ }^{12}$ The arrival of plague in 1896 brought even more stringent controls on movement, as well as the wholesale destruction of property. These heavy-handed measures inflamed political tensions and culminated in panic, strikes, and violence. ${ }^{13}$ But the nature of British rule at the beginning of the nineteenth century bore little similarity to the mature years of the Raj. Much of the Company's territory had been recently acquired and its ambitions were essentially conservative. Other differences should also be noted. Whereas later outbreaks of cholera were tracked and fairly accurately reported, the epidemics of $18 \mathrm{I}_{7}-2 \mathrm{I}$ acquired definition retrospectively, on the basis of gleanings from a variety of official papers. ${ }^{14}$ Indeed, it seems unlikely that these epidemics were viewed as discrete, sequential events, which must lead us to question the applicability of certain concepts and models used in the analysis of epidemics in the West. Of these, the most influential is the model developed by the historian Charles Rosenberg, who suggested that epidemics have similar social dynamics, resembling a play unfolding in four 'acts': progressive revelation, managing randomness, negotiating public response, and, finally, retrospection. ${ }^{15} \mathrm{In}$ particular, one might expect some divergence from Rosenberg's model in the second and third 'acts', in which societies attempt to comprehend the nature of their plight and act collectively to ameliorate it, for it seems likely that these would vary according to belief systems and modes of governance. Additionally, in the absence of anything

${ }^{11}$ Arnold, Colonizing the Body, Chapter 4 .

${ }^{12}$ Mark Harrison, 'The Great Shift: Cholera Theory and Sanitary Policy in British India, 1867-1879', in B. Pati and M. Harrison (eds), The Social History of Health and Medicine in South Asia, London: Routledge, 2018, pp. 37-6o.

${ }^{13}$ Rajnarayan Chandavarkar, 'Plague, Panic and Epidemic Politics in India, I896I9I4', in T. Ranger and P. Slack (eds), Epidemics and Ideas: Essays on the Historical Perception of Pestilence, Cambridge: Cambridge University Press, 1992, pp. 203-40; Arnold, Colonizing the Body, Chapter 5 .

${ }^{14}$ Some works published in the 1820 s and 1830 s did attempt to produce retrospective maps, but these impose a coherence that was lacking in I8I7-2I. See Pamela K. Gilbert, Mapping the Victorian Social Body, Albany: SUNY Press, 2004, Chapters 6-7.

${ }^{15}$ Charles E. Rosenberg, 'What is an Epidemic? AIDS in Historical Perspective', in his Explaining Epidemics and Other Studies in the History of Medicine, New York: Cambridge University Press, 1992, pp. 278-92. 
resembling a 'public sphere' in early nineteenth-century India, ${ }^{16}$ it is far from clear how a public response could have been negotiated.

Early colonial India provides an interesting case study in which to test the applicability of Rosenberg's model. The epidemics of I8I7-2I are sufficiently close in time to some of the examples he uses, but different enough in terms of governance, ethnic composition, and belief systems to provide illuminating comparisons. In many parts of India, the Company's dominion was fragile and customary rights and ancient beliefs continued to flourish alongside incipient modernity. By analysing how cholera was comprehended in such a context we may not only gain insights into the relationship between the colonial state and its subjects, but also into how 'modern' conceptions of epidemics may have differed from older ones.

Before doing so, it is important to consider some interpretive problems arising from the study of cholera in I8I7-2I, the most obvious of which is the absence of vernacular sources. Some vernacular literature on cholera appeared around the middle of the century, but none, seemingly, at the time. ${ }^{17}$ There are consequently few accounts of how the epidemics were understood by Indians, apart from those contained in official proceedings or reports. Nevertheless, petitions to the government and statements made in courts of law allow us occasionally to hear voices which are unmediated by either colonial officials or Indian elites. These show that most Indians attributed cholera to what would later be termed 'supernatural' causes. But whether such beliefs were related - as Arnold implies - to incursions by the British, or some grievance against them, remains to be seen. The same can be said of cholera's impact on colonial governance. In comparison with later epidemics, those of I8I72I seem to have met with a less determined response or, at least, a very different one. If so, we need to ask why this was the case and why

${ }^{16}$ That is, a relatively open 'space' in which persons, regardless of status, can participate in the discussion of common concerns. See Jürgen Habermass, The Structural Transformation of the Public Sphere: An Inquiry in a Category of Bourgeois Society, Cambridge, MA: MIT Press, 1989. According to Habermass, the public sphere is a bourgeois phenomenon, but nothing resembling a bourgeoisie yet existed in India. Its formation later in the century, together with the emergence of mass media, fundamentally altered the ways in which epidemics were perceived and the ways in which collective action was organized and critiqued. See Arnold, 'Touching the Body'; Chandavarkar, 'Plague Panic and Epidemic Politics in India'.

${ }^{17}$ See Saurabh Mishra, 'Cholera and Unani Tibb', in B. Pati and M. Harrison (eds), Society, Medicine and Politics in Colonial India, London: Routledge, 2018, pp. 6I-73; Mukharji, Nationalizing the Body, Chapter IV. 
attitudes apparently began to change in the wake of the epidemics. If Zeheter is to be believed, cholera provided an impetus for sanitary reform in the city of Madras, at least from the i8zos. But when, where, and why did such attitudes emerge? The latter question is less simple to answer than it first appears, for the links between epidemics and sanitary reform are invariably complex. Strictly functionalist accounts, in which public health measures are assumed to arise from a 'need' rendered obvious by medical threats, are unlikely to suffice. ${ }^{18}$ If we are to understand the events of I8I7-2I, we must also consider how they were regarded in the years immediately after the outbreaks, as it took some time for the epidemics to be represented as coherent events. This article therefore concludes by examining the period of retrospection that followed the retreat of cholera from India in I82I and its arrival in Europe a decade later. This period was crucial in forming the identity of cholera and in shaping common assumptions about its character and prevention.

\section{Acts of God}

Before ${ }^{18} 8 \mathrm{I} 7$, there were occasional reports of a disease known as 'cholera' in parts of deltaic Bengal and port cities throughout the East Indies, as well as a similar disease called mordechi or morxi, which some later writers came to identify as cholera. ${ }^{19}$ In both cases, it is uncertain what contemporaries were referring to. The term 'cholera' traditionally denoted an acute diarrhoeal disease or constitutional state characterized by the predominance of black bile or 'choler'. ${ }^{20}$ After 1817 , it was sometimes accompanied by descriptors such as 'Epidemic', 'Asiatic', and 'Indian', which referred to its appearance in a new and more

18 The long-held assumption that cholera epidemics were the major cause of sanitary reform in Britain has been challenged by Margaret Pelling, among others. See Margaret Pelling, Cholera, Fever and English Medicine I825-I865, Oxford: Clarendon Press, I978.

${ }^{19}$ For example, John MacPherson, Annals of Cholera: From the Earliest Periods to the Year I8I7, London: Ranken and Co., I872; John Clark, Observations on the Diseases in Long Voyages to Hot Countries, and Particularly on those which Prevail in the East Indies, London: D. Wilson and G. Nicol, I773, p. 35; James Bontius, An Account of the Diseases, Natural History, and Medicines of the East Indies, transl. from the Latin, London: T. Noteman, I769, p. 26; M. Delon, A Voyage to the East Indies, London: D. Browne, I698, pp. 237-38; Garcia da Orta, Coloquios dos Simples, e Drogas he cousas Mediçinais da India, Goa: Ioannes de Endem, I563, pp. I58-6o.

${ }^{20}$ Hamlin, Cholera, p. 20. 
deadly form. These different 'choleras' coexisted for years, making it difficult to write a continuous history of the disease. Nevertheless, descriptions of 'cholera' outbreaks in eighteenth-century India often bear a strong similarity to those that occurred in I8I7-2I, being characterized by violent purging and nervous prostration, and frequently culminating in death. ${ }^{21}$ Residents of Calcutta and other parts of Bengal had also long recognized the existence of an epidemic that was distinct from other maladies and which was associated with a local deity known as Ola Bibi or the 'lady of the flux'. As David Arnold has cautioned, this goddess may not have had an exclusive affinity with cholera, ${ }^{22}$ but the fact that no similar deity was worshipped outside of Bengal points to the existence of a disease distinct from ordinary diarrhoeal afflictions. The title bibi also suggests that this deity may have been venerated originally by Muslims or that she was given a different name by them-Hindus sometimes referred to her as Ola Candī - and this is still the case in certain parts of the delta. However, in drawing devotees from across the religious divide, Ola Bibi was by no means unique. $^{23}$ Other disease deities, including the smallpox goddess Sítalā, had a similarly mixed following and were the subjects of devotional literature and songs. ${ }^{24}$

The presence of Ola Bibi - and the disease over which she presidedwas increasingly felt. At the beginning of the eighteenth century, the only evidence of the worship of the goddess in Calcutta was a makeshift temple,

${ }^{21}$ Nalini Kanta Sirkar, 'Cholera in Calcutta - Its Sanitary and Municipal Conditions from Early Times, Part IV', Calcutta Medical Fournal, XI, I916-17, pp. 26o-63.

${ }^{22}$ Arnold, Colonizing the Body, p. I72; also Zeheter, Epidemics, Empire and Environments, Chapter I.

${ }^{23}$ In the Sundarbans nine bibis are still worshipped, each representing a particular disease. These deities are typically worshipped together, by both Hindus and Muslims, although the ceremony is normally presided over by a Muslim fakir. See Gautam Kumar Bera, Asok Kumar Mukhopadhyay and Amitabha Sarkar, 'Syncretism at Sundarbans: Anthropological and Linguistic Dimensions', in G. K. Bera and V. S. Sahay (eds), The Lagoons in the Gangeatic Delta, New Delhi: Mittal Publications, 20Io, pp. II-I2.

${ }^{24}$ On Ola Bibi generally, see Debabrata Naskar, Chabbish Paganar Loukik Debdebi: Palagan-O-Loksanskriti Fignasha, Calcutta: Dey's Publishing, I999; Fabrizio M. Ferrari, 'Devotion and Affliction in the Time of Cholera: Ritual Healing, Identity and Resistance among Bengali Muslims', in I. Vargas-O'Bryan and Zhou Xun (eds), Disease, Religion and Healing in Asia: Collaborations and Collusions, London: Routledge, 20I5, pp. 3753. On Śìtalā, see Tony K. Stewart, 'Encountering the Smallpox Goddess: The Auspicious Song of Śìtalā', in D. S. Lopez (ed.), Religions of India in Practice, Princeton: Princeton University Press, I995, pp. 389-97. 
in the form of a bamboo hut, located at Kalighat. It housed a stone said to bear her likeness which had been discovered fairly recently in the jungle by an unnamed woman. In I720, an English resident, Mr Duncan, donated Rs 4,00o for the construction of a more substantial temple. According to one story, this was done in thanks for the survival of his wife (an Indian Muslim) who had been struck by the disease. Thirty years later, Duncan gave Rs 6,ooo towards the construction of a second mandir. ${ }^{25}$ This story is significant for two reasons. First, it indicates the increasing demand for locations at which to worship the goddess. Secondly, it shows that Europeans were sometimes prepared to support the Indian population in their beliefs. This propensity to assist religious rituals persisted well into the nineteenth century, as we shall see in a moment.

When 'cholera' became epidemic, it predominantly affected Indians. In I78I, when the disease entered Calcutta with troops returning from the coastal district of Ganjam, in Orissa, there was great mortality and nearly a thousand people died within the space of ten days. ${ }^{26}$ This epidemic seems to have affected much of the eastern coast and closely followed the progress of the Bengal army led by Sir Eyre Coote. A disease said to be cholera appeared quite frequently along the eastern coast of India for the next decade, being reported as far south as Arcot. However, it does not seem to have penetrated far inland, except in I790, when cholera raged ferociously among a detachment of Bengal troops marching through the Northern Circars. In Bengal itself, there were further outbreaks of 'cholera' in Calcutta and in other towns, including Jessore, during the I79os and early I8oos. A few European troops were affected in the crowded barracks at Fort William, but most of the victims were Indians. In the i8ios, these outbreaks became more frequent and, in $1815^{-16}$, another temple dedicated to Ola Bibi was established in the Kidderpore district of Calcutta. ${ }^{27}$

Regardless of whether these outbreaks were cholera as it was later understood, there was mounting concern about the appearance of a fatal illness in parts of Bengal, which was distinguished from other

${ }^{25}$ Sirkar, 'Cholera in Calcutta', p. 26r.

${ }^{26}$ Ibid., p. 263; MacPherson, Annals, pp. I36-37.

${ }^{27}$ William Scot, 'Report on the Epidemic Cholera', Working draft of a report commissioned by the Madras Medical Board, pp. v-xiii, Papers of D. M. Moir, Writings I/ıo, Royal College of Physicians, Edinburgh (hereafter RCPE); D. E. S. Stewart-Tull, 'Vaba, Haia, Kholera, Foklune, or Cholera: In any Language still the Disease of Seven Pandemics', Journal of Applied Microbiology, 91, 200I, pp. 580-8I. 
diseases by the names oola, oota, or olāthā (in Bengali). ${ }^{28}$ Those who witnessed these outbreaks regarded them as evidence of divine anger, although there is no indication of what event had caused them to be incurred. To the extent that cholera was discussed by Europeans, it appears to have been regarded either as a contagious pestilential disease similar to plague (at least in the larger outbreaks) or, more commonly, as arising from a malignant state of the atmosphere. In the latter case, it seemed different only in degree from the common fevers of deltaic Bengal, which sometimes appeared in a virulent, epidemic form. Such fevers were regarded as products of a particularly unhealthy climate, aggravated by an abundance of putrefying matter. ${ }^{29}$

The cholera epidemic of 1817 seems to have originated in the town and district of Jessore in August of that year and shortly afterwards spread 'to an alarming extent' in Calcutta and the western and central districts of Bengal. ${ }^{30}$ These early outbreaks were reported with alacrity and in some detail, contrasting markedly with many other instances in which epidemics originated. As Rosenberg has observed, fear of the economic and politic turmoil that may ensue after the announcement of an epidemic has often resulted in attempts to conceal unusual mortality or morbidity. That was certainly the case when plague arrived in Bombay in I896, the first cases being classified disingenuously as 'bubonic fever' or 'fever'. 31 But in 1817 , medical, administrative, and revenue officials had no idea of how serious the outbreak would become or its likely ramifications. Another significant feature of the epidemic is that it began in a centre of indigo cultivation and processing, Jessore having attracted many migrant labourers, including those displaced by the erosion of traditional textile manufacture. ${ }^{32}$ Migrants moved from the

${ }^{28}$ MacPherson, Annals, p. iा.

${ }^{29}$ For example, James Lind, A Treatise on the Putrid and Remitting Marsh-Fever, which raged at Bengal in the Year 1762 , Edinburgh: C. Elliot, I776; John Clark, Observations on the Diseases of Long Voyages to Hot Countries, and particularly on those which prevail in the East Indies, London: D. Wilson, I773.

${ }^{30}$ Bengal Judicial Letter II4 I29, 29 October I8I7, Board's Collections, F/4/6io, Asia, Africa and Pacific Collections (APAG), British Library (BL).

${ }^{31}$ Arnold, Colonizing the Body, p. 203.

32 The decline of the Bengal textile industry remains controversial. Many historians have followed R. C. Dutt in dating it to the late eighteenth century, although Indrajit Ray has recently claimed that it did not go into permanent decline until the middle of the nineteenth century. It does, however, appear likely that significant change, leading to the loss of employment in weaving, for example, had occurred by the early i8oos. In addition, it is possible that higher wages in towns, commercial plantations (especially 
countryside - including parts of the delta in which cholera appears to have been endemic - into the larger towns and cities, possibly carrying the disease with them. This hypothesis cannot be proven, but it is compatible with the growing frequency of cholera outbreaks in the capital, as well as in manufacturing districts such as Jessore. As will be demonstrated below, British officials also noted a particularly high incidence of the disease among congregations of migrant labourers.

Cholera raged for several months after August I8I7, diminishing over the winter, only to reappear the following year. Between i9 September I8I7 and I7 July I8I8, 36,945 people were recorded as having been felled by the disease in Calcutta and its suburbs, only 2,382 of whom fatally. This incredibly low figure did not represent the true mortality from this disease, as even the government was forced to admit. ${ }^{33}$ But the Company's records are not the only measure of the severity of the outbreak. A separate register of deaths was kept by the Hindu crematorium at Kashee Mittens Ghat and this shows that deaths due to cholera increased sharply in Calcutta in $18 \mathrm{I} 7$ and remained high for two more years before subsiding. Mortality from dysentery and diarrhoea also peaked in these years, suggesting that some of those cases may also have been cholera.

TABLE I.

Number of bodies taken to the cemetery at Kashee Mittens Ghat for cremation. ${ }^{34}$

\begin{tabular}{lrrrrr}
\hline & 1815 & 1816 & 1817 & 1818 & 1819 \\
\hline Fever & 645 & 442 & 493 & 668 & 839 \\
Dysentery/diarrhoea & 1,081 & 852 & 1,269 & 951 & 1,083 \\
Coughs and pulmonary consumption & 223 & 153 & 147 & 149 & 140 \\
Cholera morbus & 182 & 141 & 1,323 & 2,775 & 889 \\
Various other diseases & 465 & 235 & 326 & 227 & 142 \\
Total & $\mathbf{2 , 5 9 6}$ & $\mathbf{1 , 8 2 3}$ & $\mathbf{3 , 5 5 9}$ & $\mathbf{4 , 7 7 1}$ & $\mathbf{3 , 0 9 0}$ \\
\hline
\end{tabular}

after the Permanent Settlement of I793), etc., many have attracted some labourers from traditional zamindari lands. See R. G. Dutt, The Economic History of India, Volume I: Under British Rule, I757-1837, London: Government of India Publications, I960, 2nd edn; Indrajit Ray, Bengal Industries and the British Industrial Revolution (I737-I857), London: Routledge, 20ri; Sushil Chaudhuri, From Prosperity to Decline: Eighteenth Century Bengal, Calcutta: Manohar, I995.

${ }^{33}$ Judicial Letter from Bengal, 22 July i8ı8, F/4/6Io, APAC, BL.

${ }^{34}$ Lottery Committee Minutes, Vol. II (A), 3 February i820, C. 892, Wellcome Trust Archives Centre (WTAG), Calcutta University (CU). 
Estimates of mortality in other presidencies are even less reliable, but Arnold concludes that the ravages of cholera in the west and south of India were less severe than those in Bengal. This may have been true of the first year of its appearance in those regions (1818), because cholera does not appear to have reached some areas until relatively late in the cholera 'season' (the period in which the climate seemed favourable to it) which was April to July in the case of Bombay. From August I8I8 to February 1819, on the island of Bombay, there were 24,227 reported cases, but only 938 deaths out of a population of roughly 200,000. For reasons that will be considered later, one ought to be sceptical about this seemingly low death rate. ${ }^{35}$ Arnold's discussion of cholera mortality is also confined to 1818-19, whereas official records for Bombay Island in I82I show that mortality was far higher, exceeding 'any preceding period'. ${ }^{36}$ The estimate provided by the French physician Moreau de Jonnès - a mortality of I in $\mathrm{I} 6$ or I.25 million per year for the period I8I7-3I- may not be too far wide of the mark for the years I8I7-2I, even though his method of calculation leaves much to be desired. ${ }^{37}$

The exact toll of human life must remain a matter of speculation, but the extent of mortality can be gauged from the terror it aroused. In I8I7, Charles Chapman, judge and magistrate of Jessore, informed the Bengal government that, 'The inhabitants have become so severely alarmed, that every person who was not detained here by his official situation' had left the town by the end of August. These remarks referred chiefly to Europeans and possibly also to some Indian officials working in the courts. ${ }^{38}$ Other reports suggest that the exodus was more widespread, noting 'very general emigration from the station'. ${ }^{39}$ These descriptions are in keeping with reports from other localities. The acting magistrate of Balasore, for example, reported, 'consternation among the natives, at a calamity unprecedented here is extreme'. The district of Ganjam was also said to have been 'depopulated' owing to fear of cholera. ${ }^{40}$

\footnotetext{
${ }^{35}$ Arnold, Colonizing the Body, p. I63.

${ }^{36}$ George Ogilvy, Secretary to the Medical Board, to Government of Bombay Public Department, 25 March i822, Bombay Public Proceedings, F/4/709, APAC, BL.

${ }^{37}$ Alexandre Moreau de Jonnès, Rapport au consiel supériorde santé sur le cholera morbus pestilential, Paris: Cosson, I83I, pp. 76, 84. Mortality was estimated by extrapolating from figures recorded in parts of Bengal in I8I7-2I and in the Company's armies.

${ }^{38}$ Charles Chapman to Mr Bayley, Bengal Judicial Department, 25 August I8I7, Bengal Judicial Proceedings, F/4/6io, APAC, BL.

${ }^{39}$ R. Terry, Secretary to the Bengal Medical Board, to Mr B. Bayley, Acting Chief Secretary to Government, 6 September i8I7, F/4/6io, APAC, BL.

${ }^{40}$ L. Melville to Bayley, i7 September I8I7, F/4/6io, APAC, BL.
} 
When the disease returned to Bengal the following year, there were many reports of 'consternation and alarm', indeed, of 'despair'. ${ }^{41}$ But there were none of violent unrest. This may be because such incidents remained beneath the radar of the colonial authorities, but it seems unlikely that such potentially significant events would have been unreported. It is far more likely that the absence of unrest was due to the way in which the epidemic was perceived. In Bengal, there is no evidence that cholera was ascribed to or otherwise associated with the colonial administration - at least, in any direct way. As far as it is possible to tell, the epidemics were attributed primarily to the will of deities such as Ola Bibi and Kali, although some at Jessore attributed cholera to the consumption of newly harvested rice. ${ }^{42}$ There is no indication of what was supposed to have angered the gods, but there is nothing to suggest that it had anything to do with the British administration. Devotional practices relating to both goddesses seem rather to indicate that the epidemics were interpreted as punishment for impure behaviour or insufficient veneration. ${ }^{43}$ In any case, collective action in this instance consisted overwhelmingly of displays of religious observance, for the epidemics brought many terrified people to offer devotion to both goddesses.

Although Ola Bibi was the deity most closely associated with cholera, Kali was frequently resorted to when protection was sought from cataclysmic events. Until $18 \mathrm{I} 7$, there is no indication of any competition between followers of these deities or the priests that served them, most likely because Ola Bibi had relatively few devotees. Despite her growing popularity, cholera had not prevailed to such an extent before I8I7. However, the epidemics of that and subsequent years induced far more people to seek the protection of Ola Bibi, to the evident dissatisfaction of priests at the temples of Kali. In Calcutta, they portrayed Ola Bibi as a threat to Kali and called upon the frightened populace to seek the latter's protection exclusively. Writing condescendingly of the gullibility of the people and of the artfulness of their priests, the Asiatic Fournal related the 'monstrous strategem' contrived by the Brahmans serving Kali to attract people away from the temples of Ola Bibi. The priests were said to have written a 'circular' purporting to represent the wishes

\footnotetext{
${ }^{41}$ Mr Young to C. R. Barwell, Acting Magistrate of the Suburbs of Calcutta, 3I August I8I8, Bengal Judicial Proceedings, F/4/6r7, APAC, BL.

42 'Epidemic in Bengal', The Asiatic Fournal and Monthly Miscellany, 5, I8I8, p. 448.

${ }^{43}$ Ferrari, 'Devotion and Affliction', p. 42.
} 
of the goddess, offering protection to all those who came to the temple at Kalighat. Each recipient was enjoined to copy the circular and write three more, delivering them to different parts of the city. Later, cowrie shells appeared mysteriously on doorsteps in several parts of the city accompanied by a similar leaflet. As before, the recipients were asked to deliver three more cowries and to bring them and other offerings to the temple. ${ }^{44}$

By these means, and by word of mouth, the message spread widely and the streets leading to the Kali temple were crowded for many days. However, the anxious devotees hedged their bets and many attended the nearby Ola Bibi temple before worshipping Kali. They seem to have been drawn predominantly from the 'lowest classes' and a disproportionate number were said to have been older women. However, some wealthy Hindus of both sexes were also present and attendance crossed caste, religious, and racial boundaries, and included 'Native Portuguese, Musalmans, and even Chinese'. ${ }^{45}$ Responding to the tactics of priests at the Kali temple, devotees of Ola Bibi staged

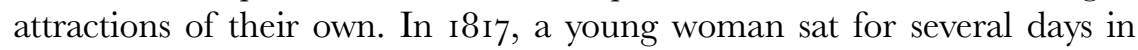
a fairly new temple at Salkea, in the suburbs of Calcutta, claiming to be an avatar of Ola Bibi, until she was encouraged to leave by the magistrate. In all these cases, the British assumed the motives behind the displays to have been pecuniary, the Asiatic fournal claiming that 'very considerable profit' had accrued to the temples as a result of the 'disgraceful' priests. ${ }^{46}$

Whether or not financial motives were paramount, there was bitter rivalry between different families or lineages (gotras) of ritualists in Calcutta. ${ }^{47}$ However, this does not appear to have involved other inhabitants of the city, most of whom sought protection from both deities, nor is there evidence of communal or other forms of conflict. If there was any intent in these gatherings other than propitiation, it seems to have been to restore social cohesion. As Dipesh Chakrabarty has suggested, such actions may have allowed communities to rediscover a lost sense of unity. ${ }^{48}$ The fact that Ola Bibi attracted many devotees from among the transient populations of the larger cities provides some

44 'Epidemic in Bengal', pp. 452-55.

${ }^{45}$ Sirkar, 'Cholera in Calcutta', pp. ${ }^{28-} 30$; 'Epidemic in Bengal', p. 454.

46 'Epidemic in Bengal', pp. 454-55.

${ }^{47}$ Ferrari, 'Devotion and Affliction', p. 45.

${ }^{48}$ Dipesh Chakrabarty, 'Community, State and the Body: Epidemics and Popular Culture in Colonial India', in D. Hardiman and P. B. Mukharji (eds), Medical 
support for this speculation, as does her intercommunal following. The worship of other disease deities in India similarly transcended social and religious divides. ${ }^{49}$

As the disease marched out of Bengal, it sometimes elicited a different response. Arnold relates a case in which the appearance of cholera in Bundelkhand was blamed on the slaughter of cattle fed to British soldiers who had marched from Bengal to fight against the Mahrattas in central India. This act not only violated the Hindu taboo against cow killing, but also took place in a grove sacred to Hurdoul Lal, the son of a former raja who was subsequently venerated as a cholera deity. Arnold then provides another example in which cholera was considered to be vengeance for disrespect shown by the Company's soldiers. On this occasion, low-caste sepoys marching through the Nellore district of Madras were said to have polluted a well that was used for religious purposes. These could easily be dismissed as isolated incidents, but Arnold also cites the opinion of de Jonnès, who claimed that Hindus in northern India attributed the epidemic to the deity 'Yagatha Ummah' who was said to have been angered by the actions of the British. On the strength of these examples, Arnold concludes that there was a 'widely shared belief' among Indians that the British were somehow responsible for cholera. ${ }^{50}$ But this generalization sits uneasily with evidence from Bengal, where there were no such reports. It is also worth noting that de Jonnès was writing at some distance-both geographically and temporally - from the events he described. Even in the areas in which Arnold has identified cholera as a focus of hostility towards the British, there were examples of cooperation in the face of the epidemic. In Bundelkhand, according to Alavi, 'both hakims and native physicians freely enlisted to help the administration tackle cholera'. These relief efforts appear to have been popular, for demand for their services exceeded supply. ${ }^{51}$

When the question of social order arose, it usually did so in relation to caste or community tensions or other local disputes in which the British were invited to arbitrate. One notable example is the case of the Christian Koli fishermen of the village of Chendnee in northern Konkan.

Marginality in South Asia: Situating Subaltern Therapeutics, Abingdon: Routledge, 2012, pp. $44^{-}-46$.

${ }^{49}$ Stewart, 'Song of Śītalā', p. 39o; Bera, Mukhopadhyay and Sarkar, 'Syncretism at Sundarbans'.

${ }^{50}$ Arnold, Colonizing the Body, p. I7I.

${ }^{51}$ Alavi, Islam and Healing, p. II3. 
Disillusioned by their Catholic priest, who refused their appeal to provide a 'remedy' for the disease, the villagers resorted to a ritual known as a khel, in which mediums incarnated a series of spirits, including Jesus, who subsequently ordained other spirit visitors. The latter were given offerings over a period of days. ${ }^{52}$ Although these rituals were certainly a measure of desperation, they were not intended by the villagers to mark their departure from the Catholic Church nor their rejection of European authority, as Arnold claims. ${ }^{53}$ The failure of the vicar to halt the epidemic was not perceived as a failure of Christianity per se but merely of the priest, who had refused to come to the village to perform a ceremony when called upon to do so by the villagers. Their continuing attachment to their adopted religion is evident from their distress at the priest's decision not to allow them to return to the fold. In September i818, the villagers appealed to Judge J. Babington of the Northern Konkan district to intervene on their behalf:

It is therefore become necessary that as you are our superior and as a parent to us, we should represent our case to you; for the order of Christ our lord to all of us is, that without the hearing of mass, we are not to catch fish or eat it; not to ascend the Bral [bael] trees; yet the padre will not come to the church to perform mass. What then can we do? We are poor people, and in order to save our lives we have instituted a ceremony from which our lives have been preserved. In doing this, what fault have we committed? If the padre had come and had provided a remedy for the epidemic we should have had no occasion to have instituted the ceremony, but he omitted to come and we therefore saved our lives by the institution of the ceremony. You are our superior, and stand in the place of our God, it behoves you therefore to take our case into consideration and to force such orders as are required. What more shall we write. This is our representation. ${ }^{54}$

A few months later, the fisherman submitted another petition to Babington, again protesting about the padre who had refused to allow them into his church to celebrate holy days such as Christmas or for the purposes of marriage, baptism, and so forth. The fishermen requested that the padre be replaced with another with whom they were familiar and mentioned that the Archbishop of Goa had resolved a similar dispute in Bombay, which had occurred after some 'coolies' reverted to a Hindu rite in the face of cholera. Although the padre had

${ }^{52}$ Arnold, Colonizing the Body, p. I74.

${ }^{53}$ Ibid., p. I75.

${ }^{54}$ Petition signed by Kooka Pastell and others, 28 September 1818, Bombay Judicial Proceedings, F/4/768, APAC, BL. 
barred them from his church, the archbishop insisted that they be allowed to attend, apparently informing the padre that 'all gods were one'. ${ }^{55}$ As a government official, Babington had no power to intervene in religious matters. Nevertheless, he offered his mediation to the vicar-general and the vicar of the church in question. According to Babington, these efforts were unsuccessful because the petitioners were 'unwilling to make the slightest atonement on the vicar for their offence'. ${ }^{56}$

Babington did nothing to conceal his frustration with the villagers, but he recognized that their partial reversion to pre-Christian practices was a temporary expedient, forced upon them by the failure of the padre to meet their expectations. Structures of authority and belief remained essentially intact. Indeed, the Kolis had sought permission from the government to stage their rituals. ${ }^{57}$ The government, too, was prepared to go no further, observing that it is an invariable maxim of the British Government to avoid interfering with the superstitions of the Natives of whatever description as they do not threaten the public tranquillity'. ${ }^{58}$

Yet the response to cholera was sometimes more violent and could not be so easily ignored. In certain districts of the Konkan, cholera was attributed to 'witches' and 'sorcerers' who were systematically murdered by roaming gangs, many of them troops disbanded from the Maratha armies. These men were without employment and apparently averse to cultivating the land. ${ }^{59}$ Their victims were mostly older women, long suspected by their communities of witchcraft, but in some cases they were men. In a typical attack, eight men were charged with the murder of a woman named Poottee, who the prisoners claimed was in the habit of converting herself into a tigress and performing various malevolent acts. She had been regarded as a sorceress for around 20 years and had previously been convicted of witchcraft by a local bhagat or person professing to unfold spells. In their testimony, her murderers declared that as 'jerry merry' (jari mari or 'sudden disease') was in their village, they thought it advisable to kill her in order to arrest the disorder. ${ }^{60}$ In

\footnotetext{
${ }^{55}$ Petition from the Christian coolies of Chendnee, 2I March i8ig, F/4/768, APAC, BL.

${ }^{56}$ J. Babington to Bengal Judicial Department, 2 February 1820, F/4/768, APAC, BL.

${ }^{57}$ Application from Patel Mattaras of the coolies of Chendnee, 22 June i819, F/4/768, APAC, BL.

${ }^{58}$ Minutes of the Bengal Judicial Department, 27 January i820, F/4/768, APAC, BL.

${ }^{59} \mathrm{~J}$. Marriotte, Magistrate of Northern Konkan, to Government of Bombay, Bombay Judicial Proceedings, 7 January I8I9, F/4/638, APAC, BL.

${ }^{60} \mathrm{~J}$. Sutherland, Report of Trial No. I, I5 February I819, F/4/638, APAC, BL.
} 
a similar incident, near Bassein, this time involving a male victim, a court of bhagats was convened to ascertain the cause of the disease and proclaimed it to be witchcraft. They then identified the perpetrator using a ceremony intended to reveal spirit possession. A man named Dharma, who had long been considered a magician, was accused. Despite professing his ignorance of magic, he was beaten to death by a band of men from the village and his body thrown into the sea. ${ }^{61}$ While the bhagats seem to have been the arbitrators, if not the instigators, of most of these incidents, in one case it was the village headman who attributed cholera to sorcery. Having consumed a fair amount of liquor, the patel brought an accused woman to his house where she was bound to a post and beaten to death by several persons. ${ }^{62}$

Though differing markedly from the responses of the villagers in Chendee or, for that matter, of Bengalis, who appear to have found solace in ritual, the murders perpetrated in the northern Konkan fulfilled a similar function. In the former cases, harmony was restored through rites that reinforced social cohesion or which - in the case of Bengal-may have promoted integration among the migrant populations of cities such as Calcutta. In the latter, the killing and beating of 'witches' exemplifies what Durkheim refers to as 'the common conscience'- the attempt to purge or chastise elements regarded as threats to social order. In all these cases, the restoration or even creation of communities appears to have been paramount, but in the case of those who perpetrated attacks on 'sorcerers', there may have been an additional element - that of compensation. At times of great upheaval, it is not uncommon for persons of low status or, in this case, those who had recently lost it to elevate their standing by transforming themselves into 'heroes and executioners', to borrow Durkheim's phrase. ${ }^{63}$

Similar responses to epidemics may be observed in many so-called traditional or pre-modern societies, but they contrast sharply with those of communities affected by cholera in Europe, less than 15 years later. In the I83os, there were many protests against the violation of traditional funeral rites and other rituals relating to the disposal of the

${ }^{61}$ John Box, Report on Trial No. 4, I5 February i8ı, F/4/638, APAC, BL.

${ }^{62}$ John Box, Report of Trial No. 5, I5 February i8ig, F/4/638, APAC, BL.

${ }^{63}$ Émile Durkheim, The Elementary Forms of Religious Life, (trans.) C. Cosman, Oxford: Oxford University Press, 2001, p. I58. 
dead. ${ }^{64}$ Some also regarded the epidemics as divinely ordained. ${ }^{65}$ Vestiges of a religious or 'customary' consciousness therefore remained. ${ }^{66}$ But it was the state and its representatives that were identified as the principal threats to these customs and the intensity of popular protest tended to reflect the level of trust that existed in any given society. Where class antagonism was sharpest and confidence in government most severely lacking, as in Russia, cholera riots and other forms of protest were severe and brutally suppressed. ${ }^{67}$ Those in Britain focused more on the activities of the medical profession, who were accused of procuring bodies for dissection. Although class tensions were certainly evident, protests were muted by comparison with those that took place in Russia. ${ }^{68}$

In both cases, however, the reaction to cholera was substantially different from that in India as the principal threat to social cohesion seemed to lie not in the actions of the state, but in factors intrinsic to afflicted communities. It may therefore be instructive to seek parallels for the epidemics of $1817-2 \mathrm{I}$ in other periods of history, most obviously the plagues of late medieval and early modern Europe. The most striking similarity is the centrality in both contexts of religious and other 'supernatural' explanations. Although some European states began to construct a machinery of public health from the Renaissance onwards, religious convictions continued to animate collective action and to shape measures taken in the name of public health. ${ }^{69}$ Another similarity lies in the persecution of minority groups (in Europe, most commonly Jews) who were blamed for the appearance of plague. This search for retribution was most obvious during the first visitations of plague in the I340s. ${ }^{70}$ Afterwards, such attacks became less common, although they

${ }^{64}$ Michael Durey, The Return of the Plague: British Society and the Cholera ${ }_{1} 8_{3-2}$, Dublin: Gill and Macmillan, I979, pp. i64-70.

${ }^{65}$ R. J. Morris, Cholera I832, New York: Holmes and Meier, I976, pp. I29-58.

${ }^{66}$ E. P. Thomson, 'Introduction: Custom and Culture', in his Customs in Common, London: Penguin, I99I, p. I5.

${ }^{67}$ Richard Evans, 'Epidemics and Revolutions: Cholera in Nineteenth-Century Europe', in Slack and Ranger (eds), Epidemics and Ideas, pp. I49-73; Roderick E. McGrew, Russia and the Cholera, I823-32, Madison: University of Wisconsin Press, I965; Louis Chevalier, Le Cholera, la première épidémie du xixe siècle, La Roche-Sur-Yon: Imprimerie Centrale de l'Ouest, I958.

${ }^{68}$ Morris, Cholera I832, pp. I08-I4.

${ }^{69}$ Samuel Cohn, Cultures of Plague: Medical Thinking at the End of the Renaissance, Oxford: Oxford University Press, 2010.

${ }^{70}$ Samuel K. Cohn Jr., The Black Death Transformed: Disease and Culture in Early Renaissance Europe, London: Arnold, 200o, pp. 232-33; William Naphy and Andrew Spicer, The Black 
occurred periodically, especially when the state's authority was tenuous. ${ }^{71}$ The fact that attacks on 'witches' followed the first appearance of cholera bears some resemblance to the killings of Jews during the first epidemics of plague, the ferocity and novelty of the outbreaks eliciting similar responses. The chief difference lay in the victims, for 'witches' were rarely scapegoats at times of plague in Europe. ${ }^{72}$

Being reminiscent of Europe's medieval past, events in the Konkan disgusted British officials. Even so, nearly all of the hundred or so perpetrators (all of whom readily admitted their guilt) were pardoned. Only one of those convicted was sentenced and transported to Penang for life. The magistrate was mindful that the killing of witches and sorcerers had been permitted under Maratha law and thought it expedient to show clemency in an area newly under British control. ${ }^{73}$ In all cases, the accused appeared to have acted in accordance with the wishes of bhagats or with their retrospective sanction, and all pleaded ignorance of the laws of the British government. However, a proclamation was issued making it known that similar crimes would be punished with death in future. Towers that had been erected in some coastal villages to enable people to hear proclamations from persons claiming to be possessed by spirits or deities were destroyed, and village officers who did not take steps to prevent 'such pernicious proceedings' were to be punished. ${ }^{74}$

These measures reflected concern over the possibility of future challenges to colonial rule, but in i8I7-2i cholera never became a focus of resistance. It would seem that the traumas and indignities of colonialism generally had no more than an indirect effect on how the epidemics were interpreted. However, there is one case (in addition to

Death: A History of Plagues 1345-I730, Stroud: Tempus, 2000, pp. 66-69; Robert S. Gottfried, The Black Death: Natural and Human Disaster in Medieval Europe, London: Robert Hale, 1983, pp. $72-74$.

${ }^{71}$ For example, the massacre of Jews in Lisbon during the plague of 1506 , which occurred after the court evacuated the capital, leaving a political vacuum. See François Soyer, 'The Massacre of the New Christians of Lisbon in 1506: A New Eyewitness Account', Cadernos de Estudos Sefarditas, 7, 2007, pp. 22I-44.

${ }^{72}$ Robin Briggs, Witches and Neighbours: The Social and Cultural Context of European Witchcraft, Oxford: Blackwell, 2002, pp. 266-67.

${ }^{73}$ J. Sutherland, Provincial Court of Circuit at Thannah, to John Box, Hon. Court of Superior Tribunal, Bombay, 22 February I8I9, and John Box, Report of Trial No. 5, I5 February i8ig, both F/4/638, APAC, BL.

${ }^{74}$ Bombay Judicial Letter, ig April I820, and Marriotte to Government of Bombay, 7 January I8I9, both F/4/638, APAC, BL. 
those mentioned by Arnold) in which cholera was directly attributed to actions taken by the British. Some years before the disease first appeared in the city of Madras in I8I8, the authorities decided to prohibit the performance of certain Hindu ceremonies on account of disputes between different castes. The ceremony in question entailed the annual procession of 'Yegattalammal', the city's tutelary goddess. At different points in the procession, representatives of the Left and Right Hand castes came forward to perform rites and present offerings. The dispute arose over who should perform certain of these rites, which reflected long-standing tensions between the two groups. ${ }^{75}$ Tutelary deities were generally credited with the power to protect their votaries from diseases, especially epidemic ones, and the disruption of the ceremony was regarded as a 'severe calamity, prognosticating the speedy destruction of the place, and the extinction, or at least the dispersion, of the inhabitants. ${ }^{76}$ Aware that this situation had the potential to corrode its authority, the government took action immediately. It brokered a deal between the Left and Right Hand castes, spelling out clearly and in detail their duties at specific points in the procession. Anyone in breach of the agreement was to be fined 5,000 pagodas. The government also disbursed money to allow the performance of rituals which were intended to diminish the force of epidemics, not only in Madras but also in rural districts such as Kanara. ${ }^{77}$

\section{Relief}

Compared to the state's response to epidemics in later decades, the actions of the Madras government appear extraordinary, for pilgrimages and religious sites became synonymous with disorder and disease. ${ }^{78}$ But tolerance and

${ }^{75}$ See Nils Brimnes, Constructing the Colonial Encounter: Right and Left Hand Castes in Early Colonial South India, London: Curzon Press, I999; Arjun Appadurai, 'Right and Left Hand Castes in South India', Indian Economic and Social History Reviewe, II, I974, pp. 216-59.

${ }^{76} \mathrm{Mr}$ Ellis, Collector of Madras, to Secretary of the Board of Revenue, I4 October I8I8, Madras Revenue Proceedings, F/4/678, APAC, BL.

${ }^{77}$ Revenue Letter from Fort St George, 2 October I8ig, and Translation of an Agreement entered into by the Heads of the Right and Left Hand Castes, 6 October I8I8, both F/4/678, APAC, BL.

${ }^{78}$ Saurabh Mishra, Pilgrimage, Politics, and Pestilence: The Haj from the Indian Subcontinent I860-1920, Delhi: Oxford University Press, 2011; Biswamoy Pati, "Ordering" "Disorder" in a Holy City: Colonial Health Interventions in Puri during the Nineteenth Century', in B. Pati and M. Harrison (eds), Health, Medicine and Empire: Perspectives on 
support for religious rituals was the norm in the I8Ios and the state often presented itself as a defender of religious customs. Its response to cholera was in keeping with this tendency to tolerate, and even to nurture, certain aspects of Indian religious life. Imbued with a paternalistic, Romantic sensibility, administrators such as Thomas Munro, John Malcolm, and Mountstuart Elphinstone sought to create a more intimate relationship between the Company and its subjects, displaying sympathy for their culture and traditions. ${ }^{79}$ By the second decade of the nineteenth century, these principles were deeply embedded, as A. D. Campbell, secretary to the Madras Board of Revenue, explained:

The Government ... have always considered it a part of their policy, to support the religious institutions of the Country and disburse annually large sums of money on this account; it has likewise been customary every where, in cases of extreme drought, to disperse sums for the performance of the 'Anavarsalay poojah', or Ceremonies for rain. ${ }^{80}$

Cholera afforded a similar opportunity to restore or cement ties between various elements of Tamil society and the colonial state, and Campbell urged the government to maintain religious customs as the best means of 'ensuring the confidence and attachment of our subjects'. 81 This did not mean that Company officials approved of these rituals, however, and some even blamed them for perpetuating the epidemic. As the surgeon William Scot put it in his 1824 report on cholera:

They flocked to the temples of their gods, and deluged the altars with the blood of numberless goats, rams and buffaloes; and having offered the head of the victim, they generally retired to regale themselves with the consecrated carcass. It is said that, in many instances, having overcharged their stomachs with this food, they the same night experienced a fatal attack of the disease. The performance of their superstitious rites subjected them to unusual fatigue, and exposed them to the vicissitudes of the climate, at the season when these were most frequent and violent. ${ }^{82}$

Colonial India, London: Sangam Books, 200I, pp. 270-98; Ira Klein, 'Imperialism, Ecology and Disease: Cholera in India, I850-1950', The Indian Economic and Social History Review, 31, 4, I994, pp. 500-04.

${ }^{79}$ Thomas R. Metcalf, Ideologies of the Raj: The New Cambridge History of India, Cambridge: Cambridge University Press, 1994, pp. 26-27.

${ }^{80}$ A. D. Campbell, Secretary to the Board of Revenue, Madras, to Chief Secretary to Government, 7 December I818, F/4/678, APAC, BL.

${ }^{81}$ Ibid.

${ }^{82}$ William Scot, Report on the Epidemic Cholera as it has appeared in the Territory subject to the Presidency of Fort St. George, drawn up by order of Government under the Superintendence of the Medical Board, Madras: Asylum Press, i824, p. Io6. 
The perceived necessity of permitting and even abetting such rituals outweighed any distaste which officials may have felt. Provincial governments also thought it expedient to offer material forms of relief, following the precedent set by intervention in the South Indian famines of 1805 and I8II-I2. On those occasions, the Company provided temporary paid employment on public works, emulating the actions of Mughal rulers. It also gave medical assistance to persons afflicted with 'fever', which was common during famines. ${ }^{83}$ Yet, whereas Indian rulers had sometimes alleviated high prices during times of scarcity, the Company steered clear of interference in the market. Famine was regarded as a natural and unavoidable calamity, requiring no more than remedial action. Cholera was understood in much the same wayas a product of uncontrollable natural forces - and initially there seemed to be no prospect of preventing it. Nevertheless, it was considered desirable to provide stricken communities with assistance.

Medical relief initially entailed the distribution of European remedies (chiefly preparations of alcohol and opium, or calomel) and later included so-called native or bazaar medicines. This was far too large a task for the Company's surgeons to attempt alone and during the first weeks of September 1817 , some $40^{-} 50$ Indian practitioners were employed by the government in Calcutta and its suburbs, the number increasing thereafter. ${ }^{84}$ At this point in time, British officials were unanimous in reporting both the efficacy of these treatments and the gratitude shown by the Indian population. On the basis of his experiences in the suburbs of Calcutta, the civil surgeon Dr Young claimed that the 'alarm, consternation and almost despair of the people, were in a degree alleviated by the sympathy shewn and the assistance administered by the European part of the population, but more especially by that humane measure of Government which directed Native Doctors with "proper" remedies to be stationed in situations where the disease was most prevalent'. Young believed that the effects of these treatments were infinitely superior to those administered by the victims' friends and relatives, who had 'indulged them with improper

${ }^{83}$ Leela Sami, 'Famine, Disease, Medicine and the State in the Madras Presidency (1876-78)', PhD thesis, University College London, 2006, pp. 34-35; Zeheter, Epidemics, Empire and Environments, Chapter I; Brimnes, 'Coming to Terms with the Native Practitioner'.

${ }^{84}$ Bengal Judicial Letter II4 I29, 29 October i8i7, Board's Collections, F/4/6io, APAC, BL. 
food and great quantities of cold water'. ${ }^{85}$ David Todd, the civil surgeon of Dacca, similarly opined that it 'is a great consolation to think many lives have been saved from the immediate assistance offered them [the people], and they [Indian doctors] are themselves more convinced of the efficacy of the European practice, namely of the giving [of] Laudanum in large doses'. According to Todd, who was writing in October I8I8, medical relief stations were now to be found along the roads from Calcutta to other major towns such as Midnapore and Burdwan. ${ }^{86}$

This system was extended throughout Bengal and maintained until at least i820. Most surgeons believed that it was the best means of managing cholera and advised magistrates to take or continue this course of action. ${ }^{87}$ In all districts and towns, magistrates and surgeons reported considerable success. In March i8ig, for example, Mr Adamson, the civil surgeon of Midnapore, claimed that although 54 persons had recently been attacked by cholera, none had died and this was confirmed by the acting magistrate. ${ }^{88}$ In Midnapore, the treatments seem largely to have been those recommended by the Company's surgeons, but in the vicinity of Jessore treatment centres established at police offices, indigo plantations, and factories dispensed local remedies alongside, and sometimes instead of, Western ones. There were several reasons for this. First, 'Bengallee medicines' such as camphor and ginger were far cheaper than their Western counterparts. Secondly, they were more popular with the indigenous practitioners employed by the Company and probably with the people they treated. ${ }^{89}$ Thirdly, they

${ }^{85}$ Statement of Dr Young to the Medical Board of Bengal, cited in letter from Dr Young to C. R. Barwell, Actg. Magistrate of the Suburbs of Calcutta, 3I August I8I8, Board's Collections, F/4/6r7, APAC, BL.

${ }^{86}$ David Todd to John Master, Actg. Magistrate of the City of Dacca, 2I October I8I8, Boards Collections, F/4/6i 7 , APAC, BL.

${ }^{87}$ Extract from Judicial Letter from Bengal, I February I820; Mr A. Pringle, Actg. Magistrate to B. Bayley, Chief Secretary to Govt., I5 March I8ı9; Mr J. Clark, Magistrate of Nuddeah to Bayley, 31 July I8ı, Board's Collections, all in F/4/746, APAC, BL.

${ }^{88}$ Adamson to Pringle, I5 March I8ı9, and Pringle to Bayley, I7 March I8ıg, both F/4/ 746, APAC, BL.

${ }^{89}$ J. Harrington, Acting Magistrate of Jessore, to Bayley, 22 April I820, and P. Stewart, Assistant Surgeon, Nuddea, to Mr Walpole, Magistrate of Nuddea, I3 June I820, Bengal Judicial Proceedings, both F/4/8I9, APAC, BL. 
seemed to be no less effective than the preparations of laudanum or calomel recommended by the medical board. ${ }^{90}$

A similar pattern may be observed in Madras. Brimnes and Zeheter have shown that the Madras government employed a variety of 'native practitioners', some drawn from among the Company's hospital assistants, but the majority of whom were practitioners of Ayurveda, Siddha, and Unani. As in Bengal, most were employed on a casual basis, being paid Rs I7.5 per month for their services, using the model devised during epidemics of fever in recent famines. ${ }^{91}$ In Bengal, the salaries paid to Indian practitioners employed in cholera work were more variable and, on the whole, lower than in Madras, ranging from Rs Io to 20 per month. ${ }^{92}$ In Madras, the district of Madura stands out on account of the enormous sums that were spent on cholera relief. In contrast to the usual salary of Rs 17.5 , Indian practitioners received a salary of Rs iı for several months throughout the cholera season of I8I9, with the result that expenditure for Madura district 'far exceed[ed]' that of others. ${ }^{93}$ The Collector justified the expense primarily in terms of its effectiveness:

... when the dreadful scourge, the cholera approached this district, I lost no time in communication with the Medical Gentlemen at the different stations to adopt every precaution possible to relieve the inhabitants from its baneful effects, and with what success the measures have been taken, statement will show of upwards of 39,000 people who were taken sick and who had medicine administered only 3,799 died, this is mainly to be attributed to the skill and attention paid by the Medical Gentlemen to those cases which came before them, and to their exertions in teaching the native practitioners, the mode of treating the disease. I trust the charges ... amounting to Rupees I0,219.4.IO will not be deemed expensive - nothing I hope when compared to the number of lives saved. ${ }^{94}$

${ }^{90}$ Dhrub Kumar Singh, 'Cholera, Heroic Therapies, and the Rise of Homeopathy in Igth Century India', in D. Kumar and R. S. Basu (eds), Medical Encounters in British India, Delhi: Oxford University Press, 2013, pp. I26-28.

${ }^{91}$ Zeheter, Epidemics, Empire and Environments, Chapter I; Brimnes, 'Coming to Terms with the Native Practitioner'.

${ }^{92}$ W. B. Bayley to Magistrate of Calcutta Suburbs, I4 July I820, and J. Barnes, Assistant Surgeon of Jessore, to J. Harrington, Assistant Magistrate of Jessore, 4 July I820, Bengal Judicial Proceedings, both F/4/8I9, APAC, BL.

${ }^{93}$ D. H. Hill, Chief Secretary to the Government of Madras, to Board of Revenue, Madras, 20 March 1820, Proceedings of Madras Revenue Department, F/4/778, APAC, BL.

${ }^{94}$ W. Peter, Collector of Madura, to President and Members of the Board of Revenue, II March I820, Proceedings of Madras Revenue Department, F/4/778, APAC, BL. 
The Collector was judged to have acted humanely, but the Board of Revenue was unable to recoup its expenses from the provincial government's central fund. ${ }^{95}$ The government deemed a bill of more than Rs I0,000 for a single district to be excessive, as most were submitting claims of less than half that amount.

Reports of the efficacy of laudanum and some local remedies may be found throughout administrative documents relating to the epidemics of I8I7-2I. Such optimism contrasts sharply with the desperation that soon began to characterize medical writings on the subject. ${ }^{96}$ It is therefore tempting to conclude that these reports were self-serving, calculated to justify the actions of local officials and medical officers. While this may be true in some cases, there is little reason to suspect that civil surgeons or magistrates were deliberately intending to deceive. The most likely explanation for their optimism is that most of the patients they treated had survived the acute stage of infection. Only the strongest or the convalescent would have been able to avail themselves of medical aid, as the majority of victims would have perished before they could reach a relief station. Furthermore, some cases may actually not have been cholera as it is now understood, but instead dysentery or diarrhoea.

Although the Company's initial response was to treat cholera as if it were a natural disaster, its recurrence in successive years showed that the government needed to be better prepared. With this in mind, it is striking that few officials suggested using measures normally employed in times of plague. These were well known to the Company and it did implement quarantine and isolation from time to time, as in 1802, when a detachment of the Company's troops returned from Egypt, and also when plague arrived in western India in the I8Ios, I820s, and I83os. On these occasions, local officials did not hesitate to impose quarantines and other coercive measures. ${ }^{97}$ Yet none of these responses were regarded as appropriate in the case of cholera. The disease did not appear to be an alien invader, like plague, but a product of India's climate. The overriding imperative was therefore to understand the relationship between cholera and meteorological conditions. As the medical response to cholera was predominantly a curative one, it was

${ }^{95}$ R. Clarke, Secretary to the Board of Revenue, to Hill, 20 March 1820, Proceedings of the Madras Revenue Department, F/4/778, APAC, BL.

${ }^{96}$ Hamlin, Cholera, p. I3I.

${ }^{97}$ Harrison, Climates and Constitutions, pp. 192-213; Zeheter, Epidemics, Empire and Environments, p. 33 . 
also important to highlight any new remedy that appeared to show promise.

In December i818, the deputy adjutant-general, Major Stuart, called for the systematic collection of observations relating to prevailing diseases and 'remarkable cases, with modes of treatment'. As the Military branch of the Bengal government wrote in a dispatch to the Company's Court of Directors, this initiative had its enthusiastic support, for it was 'Impressed with anxiety and deep concern at the distressing continuance of the fatal Epidemic, which has scourged the extensive Regions of the East with unprecedented mortality....98 ${ }^{98}$ The Bengal Medical Board quickly embraced the project and 300 letters were sent to officers of the medical establishment requesting them to note anything of interest in connection with cholera, particularly anything that might warn of its onset. This included 'changes in the general healthiness of the climate and seasons, varieties of weather and atmospheric temperature, localities of camps, cantonments and stations and all peculiarities in the condition and circumstance of Corps Establishments, as may ... appear worthy of notice'. ${ }^{99}$

That the impetus to document cholera came from the military is hardly surprising. A very serious outbreak - claiming the lives of around 6,000 men in the space of a few days - occurred in the force commanded by the marquess of Hastings in Bundelkhand in i8I8. Other serious outbreaks occurred among armies on the march and even those confined to barracks. ${ }^{100}$ However, this new initiative provided an opportunity for medical men to enhance their reputation. The secretary to the Bengal Medical Board, James Jameson, noted that while many of the Company's medical officers had made significant observations, few had bothered to 'communicate their labours to their bretheren', particularly those at home. He therefore proposed that the Board select papers written by its officers which contained 'important doctrinal views of interesting practical details and observations', adding further

\footnotetext{
${ }^{98}$ Military Letter from Bengal to Court of Directors, 26 December i818, Bengal Military Proceedings, F/4/622, APAC, BL.

${ }^{99}$ J. Jameson, Secretary of the Medical Board, to Lt.-Col. Young, Secretary to the Military Department, 30 July I8ı8, Bengal Military Proceedings, F/4/622, APAC, BL.

${ }^{100}$ Rogers, Cholera and its Treatment, p. 8; Madras Medical Board, Report on the Medical Topography and Statistics of the Presidency Division of the Madras Army, Madras: Vepery Mission Press, 1842, p. v; Edward Balfour, Statistics of Cholera, Madras: Pharoah and Co., I849, p. 3 .
} 
commentary if needed. ${ }^{101}$ Medical officers were asked to direct their attention to cholera in the first instance and, in the coming years, several volumes of reflections on this disease were sent to the Court of Directors. ${ }^{102}$ These works - some of which were later publishedconsidered all aspects of cholera, including its causes. The overwhelming tendency in the first published reports was to account for the appearance of cholera in meteorological terms, ${ }^{103}$ although a few medical officers believed that it had spread through contagion. But neither 'contagionist' nor meteorological accounts were exclusive and both began to stress the additional role played by urban conditions. It is to this subject that we shall now turn.

\section{The making of a modern disease}

One of the first reports on the epidemic of 1817 was submitted by $\mathrm{Dr}$ R. Tytler, assistant surgeon of the civil station of Jessore. Like most of those who wrote on the epidemic, he believed that it was due to a 'vitiated state of bile, occasioned by the heat of the weather, and the vast collection of water and increase of jungle ... in consequence of the excessive fall of rain during the preceding months'. Such an explanation was in keeping with received wisdom on the febrile diseases of Bengal, but Tytler introduced an additional factor, noting 'the confined nature of the natives' dwellings in the bazaar which are filled with a deleterious atmosphere, consisting of marshy vapours, unaffected by a free and salutary circulation of air'. ${ }^{104}$ Similar concerns were expressed in Calcutta and it was there that the disease first came to be regarded as a test of urban governance.

Calcutta had become an industrial powerhouse and its rapid growth attracted many migrants from impoverished areas of Bengal and beyond. Urban sprawl, congestion, and strains on infrastructure were

${ }^{101}$ J. Jameson, Secretary of the Medical Board, to Lt.-Col. Young, Secretary to the Military Department, 30 July I8I8, Bengal Military Proceedings, F/4/622, APAC, BL.

${ }^{102}$ Young to Jameson, 26 September I8I8, Bengal Military Proceedings, F/4/622, APAC, BL.

${ }^{103}$ William Scot, 'Narrative of the Progress of Epidemic Cholera in the Peninsula of India, drawn up from Records of the Office of the Medical Board', Papers of D. M. Moir, Writings i/ro, n.d, RCPE.

${ }^{104}$ Dr R. Tytler, Assistant Surgeon, to Charles Chapman, Judge and Magistrate of Jessore, 23 August I817, F/4/678, APAC, BL. 
the inevitable results. These growing pains have been documented by many historians, most of whom have noted the significance of epidemics in various phases of the city's development. ${ }^{105}$ Yet the early years of cholera have received surprisingly little attention, despite its coincidence with the formation of a Lottery Committee which aimed to improve the urban environment. The epidemics of I8I7-2I were important because they marked the first phase in the mutual shaping of a city and a disease. Proponents of urban reform - or merely those who wished to see their neighbourhood cleansed - seized upon cholera as a pretext to allocate resources to whichever localities or purposes mattered most to them.

One of the first to link cholera to worsening congestion in Calcutta was Dr R. Terry, secretary to the Bengal Medical Board, who informed the government in September 1817 that 'there is no considerable town in the low and humid climate of Bengal, that is at present entirely exempt from its [cholera's] operation - the obstruction to ventilation in native towns, from rank and luxuriant vegetation, powerfully aids the influence of the season...', adding that overcrowding was 'a powerful auxiliary to an epidemic disease'. ${ }^{106}$ Such views were shared by many non-medical officials. John Eliot, the magistrate of Calcutta Suburbs, noted that 'The disease is most prevalent in those parts of the town where it is low, particularly Burrah Bazar, Mulchoeah Bazar, Drya Hatta and Swah Bazar, and in the suburb villages of Kidderpore, Bhowanypore, Manicktullah, Kurryah, Intally, Chitpore and Sealdah. ${ }^{107}$ Eliot added that these localities were crowded with migrants from the countryside and that this compounded other unhealthy influences. These were

${ }^{105}$ For example, P. J. Sinha, Calcutta in Urban History, Calcutta: Firma KLM, I978; P. J. Sinha (ed.), The Urban Experience: Calcutta Essays in Honour of Professor Nisith R. Ray, Calcutta: Riddhi India, I987; Samita Gupta, 'Theory and Practice of Town Planning in Calcutta I8I7 to I9I2: An Appraisal', Indian Economic and Social History Review, 30, I, I993, pp. 29-55; R. Basu, 'Colonial Municipal Policy and Indian Response: Municipal Government and Police in Calcutta 1850-1872', Bengal Past and Present, I90, I, I98I, pp. I-47; Partho Dutta, Planning the City: Urbanization and Reform in Calcutta c.I80o-c.1940, New Delhi: Tulika Books, 2012; Swati Chattopadhyay, Representing Calcutta: Modernity, Nationalism, and the Colonial Uncanny, Abingdon: Routledge, 2006; Mark Harrison, Public Health in British India: Anglo-Indian Preventive Medicine 1859-19I4, Cambridge: Cambridge University Press, I994, Chapter 8.

${ }^{106}$ R. Terry, Secretary to the Bengal Medical Board, to Mr Bayley, Acting Chief Secretary to Government, 6 September, I8I7, F/4/678, APAC, BL.

${ }^{107} \mathrm{John}$ Eliot to Bayley, I5 September ${ }_{1817}, \mathrm{~F} / 4 / 678$, APAC, BL. 
conditions in which the state might legitimately intervene, as the Medical Board put it in a memorandum to the government:

The general state of the atmosphere it may not be in our power to correct, but there are powerful auxiliaries which it seems possible to remove entirely, and early measures to accomplish that Object are no doubt in the highest degree desirable; for there is no epidemic disease to which the Natives are subject, that is not produced, nourished, aided, or strengthened by their influence. ${ }^{108}$

It is easy to imagine how such observations could prompt sanitary action, but there were a number of complicating factors. In the opinion of Dr Terry, cholera was not simply a product of the environment, but of an 'unwholesome, or insufficient diet, and ... the miserable accommodation afforded by the low and damp huts of the lower and more indigent orders of the Natives'. ${ }^{109}$ In other words, cholera was also, to some degree, a disease of poverty. Dr Young similarly ascribed the epidemic to the 'High fatigue and exertion [of labourers] ... while exposed to the heat of the sun', before remarking critically on their modes of life:

The usual modes of existence among the lower classes ... [are] calculated to give rise to this complaint [cholera]; for instance, their Huts being crowded together in unwholesome situations; the want of proper ventilations in their buildingstheir custom in general of sleeping on the damp floors with merely a thin mat interposed between them and the ground,- - their habit of long fasting and then of gorging themselves with an enormous meal, composed for the most part of rice and vegetables of a cold, aqueous and acescent [sour or acidic] nature. ${ }^{110}$

Young's observation that 'the poor and labouring classes have undoubtedly appeared to be the most obnoxious to the attacks of this dreadful disease' was not intended to stigmatize them nor to portray them as a danger to others. ${ }^{11}$ Rather, he seems to have been sympathetic to their plight. If culture or personal inclinations had some bearing on who developed cholera, these things were subordinate to other conditions over which the labourers had no control, be they climate, working conditions, or poverty. In highlighting a variety of causal factors, Young's reflections on cholera differed little from

\footnotetext{
${ }^{108}$ Medical Board to Bayley, 22 September I8I7, F/4/678, APAC, BL.

109 Terry to Bayley, 22 September I8I7, F/4/678, APAC, BL.

${ }^{110}$ Statement of Dr Young to the Medical Board of Bengal, cited in letter from Dr

Young to C. R. Barwell, Actg. Magistrate of the Suburbs of Calcutta, 3I August I8I8, Board's Collections, F/4/6r7, APAC, BL.

${ }^{111}$ Ibid.
} 
contemporary accounts of fever among the urban poor in Britain. ${ }^{12}$ Most medical practitioners believed the human body to be an exquisitely sensitive organism, whose nervous energy could be drained or dangerously excited by the circumstances in which it was compelled to live and work. ${ }^{113}$ The key question for the authorities was: in which of these areas they could legitimately and effectively intervene?

The idea that the government should be involved in public health was a relatively new one in India, just as it was in Britain. Indeed, where mortality declined - such as in London - this had much less to do with public health measures than with improvements in housing, deindustrialization, migration, and falling prices. ${ }^{114}$ Intervention by the state in matters of public health was confined chiefly to the imposition of quarantine and similar measures whenever diseases such as plague or yellow fever threatened. ${ }^{115}$ Vaccination against smallpox had made some progress since it was first advocated in the I79os, but state involvement was confined to the provision (in I808) of an establishment in London to provide free vaccinations and calf lymph to vaccinators in other cities. Although vaccination had also begun in Calcutta (from I802) and in some other provincial capitals, little progress had been made by $18 \mathrm{I} 7$ and official expenditure remained low. ${ }^{116}$

With so few precedents to draw upon, intervention to control a disease like cholera was problematic. Moreover, its causes were complex. Even though it appeared to be linked to certain environmental and social

${ }^{112}$ John V. Pickstone, 'Ferriar's Fever to Kay's Cholera: Disease and Social Structure in Cottonopolis', History of Science, 22, I984, pp. 40I-I9; J. V. Pickstone, 'Dearth, Dirt and Fever Epidemics: Rewriting the History of British "Public Health", I780-1850", in Ranger and Slack (eds), Epidemics and Ideas, pp. 125-48.

${ }^{113}$ On the nervous theory of fevers and its relationship to discussions of fever in Britain and India, see Harrison, Medicine in an Age of Commerce and Empire; Christopher Lawrence, 'The Nervous System and Society in the Scottish Enlightenment', in B. Barnes and S. Shapin (eds), Natural Order: Historical Studies of Scientific Culture, London: Sage, I979, pp. 19-40.

${ }^{114}$ John Landers, Death and the Metropolis: Studies in the Demographic History of London I670I830, Cambridge: Cambridge University Press, I993, pp. 356-57.

${ }^{115} \mathrm{John}$ Booker, Maritime Quarantine: The British Experience, c.I650-19oo, Aldershot: Ashgate, 2007.

${ }^{116}$ See Brimnes, 'Coming to Terms with the Native Practitioner'; Sanjoy Bhattacharya, Mark Harrison and Michael Worboys, Fractured States: Smallpox, Public Health and Vaccination Policy in British India 1800-1947, Hyderabad: Orient Longman, 2005; David Arnold, 'Smallpox and Colonial Medicine in Nineteenth-Century India', in D. Arnold (ed.), Imperial Medicine and Indigenous Societies, Manchester: Manchester University Press, I988, pp. $45^{-65}$. 
conditions, it was unclear how these combined to produce an epidemic. Unlike smallpox, there were no obvious conclusions to be drawn about prevention. However, cholera would soon acquire a reputation as a scourge of industrial cities. Several of Bengal's towns already had a poor reputation in matters of health, but their insalubrity had hitherto been attributed to location, for the Ganges Delta was said to have the worst climate in India. On top of this, the capital, Calcutta, lay in a marshy area abutting a large salt lake, which was drained by numerous channels flowing into the River Hooghly. From the banks of these nullahs and the nearby lake, foul vapours were said to emanate during the hot and rainy seasons, leaving a heavy toll of mortality in their wake. But Calcutta was changing rapidly and this added greatly to its problems. The 'City of Palaces', as it had come to be known after Wellesley erected many grand buildings, had become notorious for squalor and overcrowding, and little had been done to improve matters. During his term as governor-general (1797-1805), Wellesley had affirmed that it was the duty of the government to 'provide for the health, safety and convenience of the inhabitants of this great town' and began to tackle the sanitary problems of the city. But after he left his post, the reforming impulse ebbed and remained weak for many years. ${ }^{117} \mathrm{~A}$ Committee of Improvement was established in 1807 to facilitate drainage, but foundered for want of funds. ${ }^{118}$

In its brief lifetime, the Committee was supported by money from public lotteries, but the proceeds had clearly been inadequate. Rather than abandon the idea altogether, the East India Company resolved in I8I7 to appoint a Lottery Committee that would have an enduring presence. The new committee was composed entirely of Europeans who were either prominent civil officials such as magistrates and revenue officers or military men with knowledge of engineering. Its remit was to consider schemes for the improvement of the city, including the extension and repair of drains and roads. Conservancy - or day-to-day sanitary work-remained within the purview of the magistrates. The conduct of this lottery was quite unlike that of public lotteries today. At first, tickets were auctioned to the highest bidder, who probably sold them to individual buyers for a share of any winnings. Later, the procedure was standardized and tickets were sold at the price of Rs Ioo

${ }^{117}$ James Ranald Martin, A Brief Topographical and Historical Notice of Calcutta: with a Sketch of the Rise and Progress of Sanitary Improvement in the East Indies, London: s. n., I847, p. II.

${ }^{118}$ Harrison, Climates and Constitutions, p. 156. 
through the Bengal Bank, a high price which put them beyond all but the wealthiest inhabitants. The buyers were chiefly Europeans, although a few Indian merchants also participated. One might therefore expect merchants and other wealthy individuals to have benefited disproportionately from the scheme and they did. But the eruption of cholera in the Committee's founding year seems to have affected its work profoundly.

The improvement of health, alongside commerce and convenience, was one the original objectives of the Lottery Committee; however, as Partho Dutta notes in his history of urban reform in Calcutta, the arrival of cholera gave its work a great deal more urgency. ${ }^{119}$ Analysis of the Committee's early proceedings confirms that public health was central to its deliberations. It did not go all out to prevent the ravages of cholera, but many proposals for improvement - which had other motivations - were couched in the language of sanitary reform. Put simply, if a nuisance seemed to present a danger to health it ascended the list of priorities. Amid a flurry of applications that urged the removal of potential sources of disease, the Committee needed to find some way of determining their real danger. It was this pressing need for discrimination that brought into being some novel ways of administering public health.

Before 1817 , the sanitary concerns of Calcuttans focused almost entirely on the problem of fevers. These concerns did not lessen and, indeed, grew stronger after the first serious epidemic of cholera, for both diseases appeared to be linked to fluctuations in the weather and also, to some extent, to poorly drained land. But cholera differed from fevers in two respects. It was more intimately connected to human filth, poverty, and urban congestion, whereas fevers were to be found in most low-lying and marshy areas, both rural and urban. Case mortality from cholera was also greater than most fevers and accordingly struck terror into the hearts of the city's inhabitants. As in most serious epidemics, the inhabitants of Calcutta sought meanings for the calamity that befell them. ${ }^{120}$ Some Europeans likened the outbreaks to the plagues that had once ravaged London, suggesting the possibility that the capital of British India, like that of Britain, might also rid itself of the disease. As G. H. Gordon, a member of the Lottery Committee, put it:

${ }^{119}$ Dutta, Planning the City, pp. 29-30.

${ }^{120}$ Much as one would expect from Rosenberg's model: see Rosenberg, 'What is an Epidemic?'. 
Those of our members even whose pursuits have been most remote from medical enquiries cannot fail to be aware of the great importance of thorough ventilation to the healthiness of a populous place or if evidence should be wanting to establish this doctrine the History of London affords a most satisfactory illustration. Previously to the burning of that metropolis in the year i666 ... the visitations of the plague were nearly as frequent and as destructive to the inhabitants, as they still are to the people of Constantinople or Cairo ... The destruction of the greater part of the Capital on that occasion afforded an opportunity which was not neglected of widening all the principal streets which till then had been excessively narrow and confined. ${ }^{121}$

The meaning of this statement would have been clear to anyone who heard or subsequently read it: Calcutta could not afford to be seen as an 'oriental' capital like Constantinople or Cairo - cities notorious for plague, corruption, and despotism. Indeed, the charge of despotism had been levelled at the Company in the recent past and the appearance of cholera seemed likely to confirm the impression that India was poorly administered. At the same time, expectations were rising. Growing affluence in Europe led the more prosperous inhabitants of cities to believe that they could remove or mitigate inconveniences which had been endured for generations. As a result, there was increasing demand for airy new towns, wide and well-paved streets, and the removal of offensive smells. ${ }^{122}$ This improving ethos had faltered in Calcutta, but if it were to become an imperial capital worthy of the name, the Committee needed to make health a priority and, above all, to remove the stigma of cholera. Gordon therefore proposed a scheme to displace much of the (largely Indian) population of north Calcutta and replace existing buildings with a geometric grid of well-ventilated streets and houses. As Dutta has noted, other members of the Committee regarded this plan as impractical and a less ambitious one was approved at its meeting of January I818. ${ }^{123}$

Nevertheless, the city's residents were now attuned to the rhetoric of public health and this became increasingly apparent in their applications for remedial works. In February I820, the Lottery Committee received the results of a survey undertaken by some of its

\footnotetext{
${ }^{121}$ Cited in the Lottery Committee Minutes, Vol. II (A), 3 February I820, No. I8, WTAC, GU.

${ }^{122}$ Vladimir Jankovic, Confronting the Climate: British Airs and the Making of Environmental Medicine, Basingstoke: Palgrave, 2010; Alain Corbin, The Foul and the Fragrant: Odor and the French Social Imagination, Cambridge, MA: Harvard University Press, I986.

${ }^{123}$ Dutta, Planning the City, p. 59.
} 
members in the northern part of the city, between Jora Begum Road and Cotton Street. On this occasion, the Committee concurred that the situation presented a real danger to health, noting that 'the quantity of filth collected in different parts of it is enough to occasion a plague'. It attributed these conditions to the neglect of conservancy and 'still more so the construction of the roads and drains'. The former were made chiefly from earth, while the latter had been badly cut, so they were unable to carry off 'liquid filth' other than during the rainy season. The prevention of 'plague' - in this case, presumably, cholera-had been subtly transformed into a problem of civil engineering. One member of the Committee, the magistrate $\mathrm{Mr} \mathrm{H}$. Shakespear, recommended that a systematic plan be drawn up for making 'pukka' streets rather than roads of earth. Calcutta's plague had become the ostensible reason for the improvement of its roads. ${ }^{124}$

Shakespear had been one of the critics of Gordon's ambitious scheme of urban reform. He believed that the improvement of roads and drainage was a more practical solution and set his weight behind a systematic review of their condition. In January I820, Shakespear formed a sub-committee with three other members to investigate the causes of a sickness that prevailed close to the central thoroughfare, Chowringee. They were charged with suggesting 'remedies for this evil', although it is unclear exactly what these might be. In this task they were given leave to consult any 'medical gentleman' if they felt the need. ${ }^{125}$ This was an important development, for while the Committee did not include any medical men, it was beginning to admit that it required their assistance. This did not extend to matters of drainage, however. Shakespear and his sub-committee reported that the conditions they had been sent to investigate were the result of stagnant water and the Committee resolved to engage the services of a surveyor to determine how far the drains should be raised to prevent accumulations of water. ${ }^{126}$

While the larger question of drainage was under consideration, the Lottery Committee received many petitions from members of the public who complained of various nuisances. In one such, the residents of Goomghur Lane (seemingly Indian and Eurasian) claimed that the narrowness of the entrance to their street meant they had to pay a double charge for bulky items to be carried in or out. It also prevented

\footnotetext{
${ }^{124}$ Lottery Committee Minutes, Vol. II (A), 24 February i820, No. I4, WTAC, CU.

${ }^{125}$ Lottery Committee Minutes, Vol. II (A), i J January I820, WTAC, CU.

126 Ibid.
} 
carts from entering to repair and clean the lane. To add urgency to these complaints, they were given a sanitary gloss:

This is an inconvenience that is felt by us most severely particularly in the present damp weather when the unwholesome exhalation arising from accumulated and accumulating dirt and filth in a narrow passage is so likely to be attuned with the most prejudicial consequences to the health of all those who unfortunately are exposed to its baneful influence. ${ }^{127}$

The residents probably calculated that their interests would be best served if they couched their demands in sanitary terms, but on this occasion they failed to convince the Committee. They tried on three further occasions to obtain its assistance but to no avail. In its final reply, the Committee stated that it 'did not discover in these Papers any adequate reason' to change its mind. ${ }^{128}$ In its view, no compelling case had been made for the nuisances to be considered a substantial threat to public health. Although there may have been other reasons for the Committee's decision - the fact that European residents experienced little inconvenience was no doubt high among them - the 'sanitary test' imposed by the Committee provided a rationale for prioritizing the applications it considered important and rejecting those that it did not. If need be, the Committee could also call upon the services of medical men to determine whether or not nuisances constituted a serious threat to public health.

The Lottery Committee used similar arguments when it made supplications to the government for loans to purchase land, as one can see in its attempt to buy a large plot owned by a wealthy European resident, Mr Camac. The Committee partly funded its activities by purchasing land, improving it, and selling it at a profit. In the case of larger tracts, it sometimes sought a loan from the government, as did in the case of Mr Camac's property. The government sanctioned a loan of Rs 3 lakhs (Rs 300,000) for the compulsory purchase and improvement of this land, which abutted the main thoroughfare of Chowringee. ${ }^{129}$ The Committee justified the purchase chiefly on the grounds of epidemic prevention, insisting that the 'health and comfort of thousands' depended upon it. ${ }^{130}$ The land's proximity to European

${ }^{127}$ Lottery Committee Minutes, Vol. II (A), Letter from the inhabitants of Goomghur Lane, 27 September i818, Meeting of 3 February i820, No. 22, WTAC, CU.

${ }^{128}$ Lottery Committee Minutes, Vol. II (A), 3 February I820, No. 23, WTAC, CU.

${ }^{129}$ Lottery Committee Minutes, Vol. II (A), I8 May i820, No. I, WTAC, CU.

${ }^{130}$ Lottery Committee Minutes, Vol. II (A), Report of the Sub-Committee on Sickness, 4 May i820, No.I7, WTAC, CU. 
dwellings was most likely an important consideration. However, the same principles could sometimes restrict the ambitions of the Committee. In I820, its members were made aware of a sanitary problem in the low-lying settlement of Birjeetalao, to the west of Chowringhee. The area lay between the house occupied by Fort William College and that of the Persian secretary to the government and was therefore potentially of some interest to the government as well as to the Committee. In I8I8, the latter formed a sub-committee which visited the site and reported on possible remedial measures. ${ }^{131}$ The governor-general was informed that the land was covered in tanks and pools which made it 'extremely noxious', possibly in the hope that the government might be interested in assisting in the purchase of the land or at least in securing its endorsement of some potentially drastic measures. However, before making any recommendation to the Lottery Committee, the governorgeneral (the marquess of Hastings) requested 'careful examination' of the ground by 'a person with professional experience' (that is, a doctor) in order to 'estimate the degree of danger to which the health of the inhabitants may be exposed'. ${ }^{132}$ In this case, the inhabitants were Indian, even though there were significant European settlements nearby.

The governor-general's request provides further evidence that professional expertise was becoming important in questions of urban governance in the wake of cholera. In this case, the person chosen to conduct the survey was Dr James Jameson, the newly appointed secretary to the Bengal Medical Board and author of a recently published report on cholera in the years $18 \mathrm{I} 7-\mathrm{I} 9$. This report was commissioned by the government and was based on numerous individual testimonies. It also incorporated the opinions of Indian practitioners who had been employed by the Company during the epidemics. ${ }^{133}$ The report concluded that the outbreak was triggered by meteorological 'irregularities' such as heavy rains, fluctuations in temperature, and easterly winds, ${ }^{134}$ but added that it was 'materially affected by localities of situation', being most fatal in areas that were

${ }^{131}$ Lottery Committee Minutes, I5 March i818, 9 March i820, WTAC, CU.

${ }^{132}$ Lottery Committee Minutes, 20 July I820, No. I3, Letter i: W. B. Bayly, Chief Secretary to Govt., to Dr J. Jameson, Secretary to the Medical Board, I9 May I820, WTAC, GU.

133 As discussed in Alavi, Islam and Healing, p. II4.

${ }^{134}$ James Jameson, Report on the Epidemick Cholera Morbus, as it Visited the Territories subject to the Presidency of Bengal, in the Years I8I7, I8I8, and I8I9, Calcutta: Government Press, I820, pp. lxvii, 87 , I00. 
'low and manifestly unwholesome'. ${ }^{135}$ In Calcutta, it noted, 'the disease was, from first to last, most prevalent in the lower parts of the town and suburbs', localities adversely affected by dampness, poor drainage, rotting vegetation, and poor ventilation and housing. ${ }^{136}$

Jameson's 1820 report to the Lottery Committee reiterated these points and provides some insight into the ways in which sanitary dangers were assessed. One of the first things mentioned by Jameson was that the land was covered with 'ranges of small huts situated nearly in close contiguity to one another, and occupied by the very lowest descriptions of the Natives'. These were precisely the conditions in which cholera had first appeared in Calcutta and among the same type of peoplemigrant labourers. ${ }^{137}$ If such a report had been published 50, or perhaps even ten, years later, the proximity of such dwellings to government buildings would have been a major cause of concern and their inhabitants stigmatized as reservoirs of disease. But in Jameson's description they appear largely as potential victims. While they were blamed for allowing 'animal filth' to accumulate on the land, the chief threat to their health came from the ground they occupied, specifically from three shallow tanks filled with foul water, as well as defective drainage of the ground on which their privies were located. Jameson's first concern was to determine whether these conditions made the inhabitants unhealthy and he made enquiries to this effect when he visited the site, taking the trouble to ask the residents themselves. He found that 'the Situation is not considered by any means unhealthy', confirming his previous impressions of the area. He also noted that European families in the vicinity appeared to suffer no diseases arising from the foul state of the neighbourhood. As a result, Jameson and the Medical Board were 'at a loss to propose any other expedients for the removing [of] the consequences arising from the state of this tract, than the obvious ones of filling up [and] deepening the tanks, and removing the necessaries from the European part of the town'. ${ }^{138}$

This must have been disappointing to those members of the Committee who favoured more radical intervention. Jameson was sympathetic to this and admitted that:

135 Ibid., p. 106.

${ }^{136}$ Ibid., pp. Io8-o9.

${ }^{137}$ Lottery Committee Minutes, 20 July i820, No. I3: Letter 2: Dr J. Jameson to Chief Secretary to Govt., I8 June I820, WTAC, CU.

${ }^{138}$ Ibid. 
The total destruction of the huts and the appropriation of the ground now occupied by them [the labourers] for large buildings would unquestionably add considerably to the comfort and agreeableness of the neighbourhood, and to the beauty of the City and the Board would have no hesitation of recommending of this measure, provided that it could be effected without injury to the present landholders. Unfortunately, the evils under consideration are not confined to this one spot- - [the] great part of the ground lying near to the principle [sic] streets of Chowringhee and the European Division of Calcutta is in an equally foul and corrupt state, which, the Board fear, can only be ameliorated by the introduction of extensive municipal measures, such as widening the streets, regularly cleansing the drains, supplying the City with running water. ${ }^{139}$

In Jameson's opinion, such an ambitious programme of reform was unfeasible and the government came to the same conclusion. The governor-general in Council observed that 'the immediate danger to be apprehended from the state of the ground alluded to ... does not appear to demand the adoption of any special measures of preservation [i.e. compulsory purchase]'. ${ }^{140}$ Instead, he recommended that the Lottery Committee conduct remedial measures on a more limited scale. In the event, the Committee bought a small parcel of land adjacent to the tract in order to build a new water tank. ${ }^{141}$

\section{Retrospection}

In the coming years, the sanitary criterion - 'the degree of danger' - was applied to most of the schemes proposed by the Lottery Committee or to the appeals made to it for remedial action. The plan originally advanced by Shakespear, for example, foregrounded health even though the principal objective seems to have been commercial. In September i820, Shakespear took this a step further when he proposed the formation of a sub-committee on drainage with an operating budget of Rs 2,00o per annum. The ostensible purpose of the sub-committee was to effect works of improvement that would benefit 'the health and comfort of the inhabitants'. The same reasons were given to justify his proposal to pave roads currently covered by earth. ${ }^{142}$ In the following year, the Committee was asked by the government to judge the feasibility of a

${ }^{139}$ Ibid.

${ }^{140}$ Ibid.

${ }^{141}$ Dutta, Planning the City, p. 37.

${ }^{142}$ Lottery Committee Minutes, 2I September i82o, No. I3, WTAC, CU. 
fairly ambitious scheme for improving drainage in the city proposed by one of its members, Lt. J. A. Schlach. The governor-general was 'inclined to think well of it' and requested the Committee to consider, among other things, 'the probable influence of the proposed work on the health and cleanliness of the city'. He stressed that this was as much an 'obvious a point of enquiry, as the degree in which it may be calculated to facilitate commercial intercourse'. ${ }^{143}$ In other words, the government now attached great importance to any scheme for preserving the health of the capital. While it was not proactive in this regard, it was keen for the prevention of epidemics to remain central to the work of the Committee. The Committee therefore continued to dress all schemes requiring government approval in sanitary clothes. For example, in September i82I, it wrote a letter to the government asking it to sanction a proposal from Shakespear for the construction of a new road, at a cost of Rs I6,603. It was to be 40 feet wide and to run from Bow Bazar to Neemtollah Street, its purpose being to 'contribute to the Health, Comfort \& Convenience of the Inhabitants' of that part of the city. ${ }^{144}$

This association between cholera, congestion, and filth would be reiterated time and again, wherever and whenever the disease appeared. Such ideas were communicated in the first instance through reports written in India during and shortly after the epidemic, although only one - that written by William Scot of the Madras presidency - was able to comprehend the events of $1817-2 \mathrm{I}$ in their entirety. Furthermore, as Scot admitted in a later edition of his 1824 report, his initial assessment lacked clarity and was swollen to an unhelpful degree by meteorological tables and other relatively undigested data. ${ }^{145}$ However, by the time cholera arrived in Europe, Anglo-Indian opinion had become more definite. The link between cholera and filth was generally accepted and had become part of a cultural and moral critique that aimed to elevate Western over Indian civilization. This reflected a general shift in attitudes towards the governance of India and a movement away from conservative forms to those which sought to apply universal principles based on scientific rationality, as

${ }^{143}$ Lottery Committee Minutes, 25 August i821, No. I, WTAC, CU.

${ }^{144}$ Lottery Committee Minutes, I3 September, No. 9, WTAC, CU.

${ }^{145}$ William Scot, Report on the Epidemic Cholera as it has appeared in the Territory subject to the Presidency of Fort St. George, drawn up by order of Government under the Superintendence of the Medical Board, Edinburgh: William Blackwood, ı849, later edn, pp. i-ii. 
understood by such thinkers as James Mill and David Ricardo. ${ }^{146}$ Poor sanitation - and its concomitant, disease - were perceived as barriers to efficiency and reflected badly on imperial administration. Formerly localized concerns about urban nuisances were consequently transformed into a broader agenda for reform, most obviously under Lord William Bentinck, governor-general from 1828 to 1835 . This new attitude is exemplified in the various writings of James Ranald Martin, most obviously his Notes on the Medical Topography of Calcutta (1837), an amalgam of imperialistic hubris, utilitarianism, and evangelical Christianity. ${ }^{147}$ Writing shortly after Calcutta had experienced a second major epidemic of cholera, Martin no longer saw the urban poor as victims, but rather as material for reform, requiring 'the influence of education and European example'. ${ }^{148}$

This change in tone owed something to Britain's own recent experiences with cholera as well as the growing influence of utilitarian ideas upon public administration. However, it is interesting to note that the framing of cholera as a sanitary disease was initially resisted in Britain. In some respects, this is surprising in view of the growing interest in, and awareness of, colonial knowledge in medical centres such as Edinburgh and London. ${ }^{149}$ However, professional bodies such as the royal colleges were in the habit of mediating the transmission of ideas and practices from the colonies and some were steadfastly resisted. ${ }^{150}$ This was initially true of Anglo-Indian opinions on cholera, for as Scot explained in I849, only a few of the original reports reached Britain or were published before the arrival of cholera in 183 I. ${ }^{151}$ Some

${ }^{146}$ Eric Stokes, The English Utilitarians and India, Oxford: Oxford University Press, I959; Javed Majeed, Ungoverned Imaginings: James Mill's The History of British India and Orientalism, Oxford: Clarendon Press, I992.

${ }^{147}$ James Ranald Martin, Notes on the Medical Topography of Calcutta, Calcutta: G. H. Huttman, 1837 .

${ }^{148}$ Ibid., p. 47. For a more detailed discussion of Martin's work and its place in changing discourses of health, see Partho Datta, 'Ranald Martin's Medical Topography (1837): The Emergence of Public Health in Calcutta', in B. Pati and M. Harrison (eds), The Social History of Health and Medicine in Colonial India, Abingdon: Routledge, 2009, pp. I5-30; Harrison, Climates and Constitutions, Chapters 3 and 4.

${ }^{149}$ Pratik Chakrabarti, Materials and Medicine: Trade, Conquest and Therapeutics in the Eighteenth Century, Manchester: Manchester University Press, 2010; Harrison, Medicine in an Age of Commerce and Empire.

${ }^{150}$ See Londa Schiebinger, Plants and Empire: Colonial Bioprospecting in the Atlantic World, Cambridge, MA: Harvard University Press, 2004.

${ }^{151}$ Scot, Report on the Epidemic Cholera (1849), p. i. 
of those that were published also received short shrift from the medical 'establishment', which had a distinct preference for the handful of Anglo-Indian writers who supported the theory of contagion.

One such was Reginald Orton, who had returned to Britain prior to the outbreaks of the i83os. ${ }^{152}$ Orton had originally subscribed to the climatic theory of cholera, but had become an ardent convert to the theory of contagion, as one can see from the public role he assumed after returning to Britain. In 1832, having again encountered cholera while working at the Military Cholera Hospital in Westminster, he claimed that there was definite proof of its transmission from person to person. ${ }^{153}$ Some other practitioners with Indian experience shared his views and recommended a response - quarantine - which was commensurate with their beliefs. ${ }^{154}$ Their opinions chimed with those of the Royal College of Physicians, which had previously advocated quarantine in the case of plague and yellow fever, both of which had spread widely during the recent wars with France. ${ }^{155}$ After the great epidemics in India, members of the College once again urged the need for quarantine and denounced views to the contrary, including those expressed by the majority of Anglo-Indian practitioners.

One of the great proponents of quarantine was the former naval doctor Sir Gilbert Blane. He was a close confidant of statesmen and the royal family, which he had served as a physician. Although Blane had experienced yellow fever during his time in the Navy, he had never witnessed an outbreak of cholera. Nevertheless, in 1825, when the Company's Court of Directors decided to seek his opinion on the reports emanating from India, Blane took issue with those who denied that cholera was contagious. First, he pointed out that many of the arguments against contagion were weak, insisting that contagious diseases often left many of those exposed to victims untouched, their susceptibility or otherwise being easily explained by reference to predisposing factors. Similarly, the fact that no contagious agent had yet been identified was not an obstacle to accepting an infectious mode of

${ }^{152}$ Reginald Orton, An Essay on the Epidemic Cholera of India, London: Burgess and Hill, I83I, especially pp. 346-47.

${ }^{153}$ Reginald Orton, 'Observations on the Malignant Cholera in England', The Lancet, I9, 475, 6 October I832, pp. 43-45.

${ }^{154}$ James Kennedy, The History of the Contagious Cholera: with Facts explanatory of its Origin and Laws, and of a Rational Method of Cure, London: James Cochrane and Co., I83I, pp. 24I-6o.

${ }^{155}$ Harrison, Medicine in an Age of Commerce and Empire, pp. 254-86. 
transmission. Hardly anyone doubted the contagiousness of smallpox, even though its causal agent remained elusive.

When it came to evidence for contagion, Blane insisted that cholera had spread from India to other parts of Asia and attempted to prove this in a brief history of what he termed 'the Epidemick'. This noted cholera's emergence in Bengal and its spread from there to other parts of India and subsequently to other countries by land and sea. Of particular significance is Blane's discussion of cholera in the two French Indian Ocean colonies of Île de Bourbon (Réunion) and Île de France (Mauritius). He wrote that there was ample evidence that the disease had arrived at the latter on the frigate Topaz, from Ceylon, and that it was inconceivable that the disease could have travelled through the atmosphere over such a vast distance. Related to this contention was Blane's decision to reject the term 'Indian cholera', which implied that there was some atmospheric or other peculiarity involved, and his preference for the term 'malignant spasmodic cholera', which had no association with place. Lastly, Blane argued that the contagiousness of cholera could be inferred from the fact that the use of sanitary cordons in Île de Bourbon had stemmed the spread of the disease, whereas the lack of such measures on Île de France had allowed it to spread freely. ${ }^{156}$

A narrative of the first great wave of cholera was therefore constructed retrospectively, imposing a structure and unity that had not been obvious to most of those who had witnessed it. Contemporaries had sometimes used the term 'epidemic' to describe these events, but usually in a looser sense than Blane, that is, to denote outbreaks of a 'similar' disease occurring at more or less the same time in different localities. ${ }^{157}$ Only the last report - Scot's, in I824 - presented a narrative of the epidemic's progress over the years from i8I7. The description of cholera as a 'disorder' (a term used far more frequently than 'epidemic' in the years I8I7-I8) better conveys the confusion which surrounded the outbreaks while they were still in progress. It is also notable that these narratives were written by persons who were prepared to entertain the notion of contagion (such as Scot) or who were strongly committed to it (such as Blane). As Scot admitted, this was very much a minority position

${ }^{156}$ Sir Gilbert Blane to the Court of Directors, I6 January I825, Observations on Cholera Communicated by Sir Gilbert Blane to the Court of Directors, F/ $4 / 767$, APAC, BL.

${ }^{157}$ For example, R. Terry, Secretary to Bengal Medical Board, to Mr B. Bayley, Acting Chief Sec. to Govt., 6 September i8ı7, Board's Collections, F/4/6io, APAC, BL. 
among the Company's medical officers in India. ${ }^{158}$ However, Blane insisted that cholera was similar to plague and yellow fever, and he referred to the former as the 'Great Epidemick of the East', just as he styled yellow fever the 'Great Epidemick of the West'. ${ }^{159}$ Their equivalence lay not only in their mode of spread, but in their expansion beyond what were presumed to be their natural domains. This made both diseases an imminent threat to security; through this narrative, exponents of contagion hoped to consolidate their position by equating it with the defence of the realm.

After cholera appeared in European Russia in 1830, Blane and like-minded physicians again counselled the need for quarantine. Their views were received favourably by the Central Board of Health, which strongly favoured the contagion theory, putting into place measures similar to those that had been used to prevent plague and, more recently, yellow fever. ${ }^{160}$ The Board also looked favourably on the few contagionist accounts written by practitioners who had witnessed cholera in India, Orton's treatise being singled out by one of its members, Sir James McGrigor, as 'one of the best on the subject'. Now director-general of the Army Medical Department, McGrigor had served as a military surgeon in Bombay and was a close confidant of Arthur Wellesley, later duke of Wellington. His views on contagion and quarantine were almost identical to those of Blane and in keeping with those of the political establishment. ${ }^{161}$

In the long-run, however, it was the sanitary narrative that would prevail over these straightforwardly contagionist accounts, Orton's treatise later being criticized as insignificant and obscure. ${ }^{162}$ This assessment was rather unfair, but Orton's opinions were certainly unrepresentative of Anglo-Indian practitioners, as fewer than 30 of them were said to be convinced 'contagionists', that is, adherents to a position which held that cholera was a specific disease spread by human contact

${ }^{158}$ Scot, Report on the Epidemic Cholera (1824), p. Io6.

${ }^{159}$ Blane to Court of Directors, i6 January I825, F/4/767, APAC, BL.

${ }^{160}$ Gilbert Blane et al., Cholera Morbus: Its Causes, Prevention and Cure; with Disquistions on the Contagious or Non-Contagious Nature of this Dreadful Malady, by Sir Henry Halford, Sir Gilbert Blane, and eminent Birmingham Physicians, and the Lancet, and Medical Gazette, together with ample Directions regarding it, by the College of Physicians and the Board of Health, Glasgow: W. R. M'Phan, I831.

${ }^{161}$ Harrison, Medicine in an Age of Commerce and Empire, pp. 259-6o.

${ }^{162}$ Letter to the Editor from 'Chiron', 3July I831, The Lancet, I6, 4Io, July i831, pp. 47677; Letter to the Editor from J. Gilchrest, Io October I831, 'Respecting some Statements on the Paper of Mr Orton', The Lancet, I9, 477, 20 October 1832, pp. II3-16. 
or via media such as textiles. ${ }^{163}$ The majority of those who put pen to paper on the subject of cholera emphasized the sanitary and climatic factors they believed to be responsible for the erratic spread of cholera in India and subsequently in Britain. Its uneven progress seemed to suggest that other influences were at work. Opinion in Britain and India thus became mutually reinforcing, establishing a kind of 'common sense' about the conditions under which cholera flourished

One of the most influential figures in this regard was Dr James Johnson, a former naval surgeon who had been stationed in Calcutta and who subsequently became famous as the author of the frequently republished Influence of Tropical Climates on European Constitutions (1812), as well as numerous pamphlets offering advice to 'tropical invalids' and others suffering from ailments of the stomach and bowels. ${ }^{164}$ As founder and editor of the Medico-Chirurgical Review, Johnson's views on issues such as contagion and quarantine - matters on which he took a moderate position - were well known before the arrival of cholera in Britain. ${ }^{165}$ On the basis of his experience of cholera in India in the years before I8I7, Johnson claimed that it had arisen largely from factors beyond human control. In his view, most epidemic diseases were caused by foul vapours emanating from the bowels of the earth. However, he conceded that these diseases could acquire greater intensity, and even become contagious, in overcrowded or filthy conditions. On the whole, he was satisfied that cholera would not spread far if it arrived in Britain, as the country's temperate climate would limit its duration. Indeed, he insisted that dread of disease played a far greater part in inducing cholera than atmospheric conditions - an opinion that reflected the common view that fear disposed a person to various forms of fever. The surest preventives were therefore temperance of body and equanimity of mind. ${ }^{166}$

Such optimism seemed misplaced after cholera arrived in Britain, but many came to share Johnson's opinion that its spread had been

${ }^{163}$ Morris, Cholera 1832, p. I8I. 'Contagionism' was not an exclusive position but a tendency to place more weight on person-to-person transmission in accounts of disease outbreaks than on other factors, such as environmental or sanitary causes. Most practitioners incorporated elements of both in their views on cholera. See Pelling, Cholera, Fever and English Medicine.

${ }^{164}$ Durey, The Return of the Plague, pp. II4-16.

${ }^{165}$ Harrison, Medicine in an Age of Commerce and Empire, pp. 227-36

${ }^{166}$ Letter from James Johnson to the Editor, 25 June I831, The Lancet, I6, 409, 2 July I83I, pp. $422-24$. 
mediated by local conditions. Johnson continued to express these opinions in exchanges with opponents in the medical press as well as in public debates, such as those held at the London and Westminster medical societies. In one such debate, Johnson claimed that the dissemination of cholera among nurses at Guy's Hospital could only be explained by what he termed an 'epidemic influence', as none had been in direct contact with cholera patients. These comments echoed remarks he had made in many of his published works concerning the deleterious effects of urban life. ${ }^{167}$ Speaking in the same debate, however, Orton declared the contrary, insisting that he found the facts in favour of contagion in the London outbreak to be 'irresistible'.

Johnson and Orton were by no means the only Anglo-Indians who essayed opinions on cholera. Indeed, Johnson's most important contribution was perhaps to bring to light the writings of other practitioners who had served in India. ${ }^{169}$ One of these was James Jameson whose Report on the Epidemic Cholera Morbus was published in I820. As we have seen, Jameson focused on the conditions to be found in urban areas and particularly on the vulnerability of the poor. In this sense, his account differed from Johnson's more exclusive concern with meteorological phenomena-a shift of emphasis which may be explained by the fact that Jameson witnessed the epidemics of I817-21, whereas Johnson had only encountered cholera earlier and in sporadic form. ${ }^{170}$ With their 'untamed' vegetation and tropical heat, Indian cities may not at first have seemed analogous to Western ones, but the basic principle appeared to be the same: cholera thrived in insanitary conditions, whether these resulted from abundant foliage or what Jameson referred to as "wretched, overcrowded housing. ${ }^{171}$ Addressing these problems, some argued, was a better bet in preventing cholera than resorting to quarantine, which patently had not worked in $\mathrm{I}_{3} \mathrm{I}^{-}$ 32. ${ }^{172}$ For those who opposed the practice on commercial grounds,

${ }^{167}$ Harrison, Medicine in an Age of Commerce and Empire, pp. 233-36.

168 Transcript of Meeting of Westminster Medical Society, 31 March 1832, The Lancet, I8, 449, 7 April I832, pp. 2I-24.

${ }^{169}$ See, for example, the synopses of cholera reports and treatises in James Johnson, The Influence of Tropical Climates on European Constitutions, London: Thomas and George Underwood, I827, pp. $275 \mathrm{ff}$.

${ }^{170}$ Jameson, Report on the Epidemick Cholera Morbus, p. Io6.

171 Ibid., p. Iog.

${ }^{172}$ For example, James McCabe, Observations on the Epidemic Cholera of Asia and Europe, Cheltenham: G. A. Williams, I832, pp. 5-6; William White, The Evils of Quarantine Laws, and Non-Existence of Pestilential Contagion, London: Effingham Wilson, I837. 
these views were not only welcome, but would become their principal argument for reform or repeal of quarantine laws. ${ }^{173}$

Anglo-Indian medical texts provided an interminable supply of evidence for the non-contagion of cholera, many of which were written for the benefit of readers in Britain. In a monograph published in London, William Twining of the Calcutta General Hospital insisted that the main factor determining whether or not cholera broke out in a particular locality were its sanitary conditions. ${ }^{174}$ T. J. Pettigrew, who had returned from India to become principal surgeon at the Royal West London Infirmary, Charing Cross Hospital, and the Asylum for Female Orphans, also reminded his readers that cholera had originated in 'a crowded, dirty, ill-ventilated town' (Jessore) and that everywhere it had spread 'its attacks in the first instance were chiefly confined to the lower classes of people, to those whose constitutions had been broken down by hard labour, imperfect nourishment, inadequate clothing, and whose duties occasioned them to be exposed to all the severities connected with low and foul situations. ${ }^{175}$ As far as Pettigrew was concerned, the problem of sanitary conditions was inseparable from that of poverty, and cholera could be prevented by 'Free ventilation, cleanliness, good diet, proper clothing, [and] abundant fuel'. ${ }^{176}$ However, he made no suggestions as to who should be responsible for providing these things.

Another surgeon who acknowledged the link between filth and poverty was James Adair Lawrie, formerly in medical charge of the Bengal Native Infantry and Civil Surgeon of Moradabad and later professor of surgery at the University of Glasgow. Writing in $183^{2}$, towards the end of the first epidemic in Britain, Lawrie declared cholera to be much the same in both countries, the only difference being that in Britain it was even more closely confined to insanitary localities, particularly those close to rivers; indeed, Lawrie wondered whether the disease might be water-borne in some cases. ${ }^{177}$

${ }^{173}$ Peter Baldwin, Contagion and the State in Europe 1830-1930, Cambridge: Cambridge University Press, I999, pp. I23-29.

${ }^{174}$ William Twining, A Practical Account of the Epidemic Cholera, and of the Treatment requisite in the various Modifications of that Disease, London: Parbury, Allen and Co., I833, p. 270.

${ }^{175}$ T. J. Pettigrew, Observations on Cholera; comprising a Description of the Epidemic Cholera of India; the Mode of Treatment and the Means of Prevention, London: S. Highley, I831, pp. 7, 22.

${ }^{176}$ Ibid., p. 33 .

${ }^{177}$ James Adair Lawrie, Essay on Cholera, Founded on Observations of the Disease in Various Parts of India, and in Sunderland, Newcastle, and Gateshead, Glasgow: J. Smith and Sons, I832, pp. II-I4, 22, 47 . 
While all these works placed sanitary factors in a broader causal framework, they distinguished between 'exciting' causes (such as bad air) which were necessary to produce attacks of cholera and 'predisposing' ones, such as fatigue, debauchery, insufficient diet, and inadequate clothing or housing, which made attacks of cholera more or less likely. The Bengal surgeon Frederick Corbyn thus recommended a range of measures that aimed at both personal protection and the removal of sanitary nuisances. ${ }^{178}$ The distribution of cholera socially and geographically seemed to depend on how these factors combined and the ability of individuals to resist exposure to noxious vapours. While the poor were generally more susceptible to such influences, this was not always the case, for much also depended upon habit. In a letter to The Lancet, the Army surgeon John Malcolmson noted that while the rich in India generally suffered little from the disease, Brahmans were sometimes as susceptible as the lower castes on account of the filthy localities they sometimes inhabited. ${ }^{179}$ On the whole, it would seem that cholera tended to accentuate the dangers of places or forms of behaviour that were already regarded as hazardous. But it also produced some new concerns and correspondingly novel solutions. In a pamphlet of 1831, the Army officer Lt.-Col. Rowles used his Indian experience to argue that the disease was propagated in accumulations of corpses, such as those that had formed in Indian cities or along the routes traversed by the Company's armies. He saw particular problems for those British cities that had burial grounds in their midst and recommended cremation as the 'only effectual resource' to which 'we must come sooner or later'. ${ }^{180}$ This suggestion considerably predates the formation of the Cremation Society in London in 1874 and seems to have been singular at this time, even though other surgeons with Indian experience adverted to decaying corpses as a contributory factor in the spread of cholera. ${ }^{181}$

\footnotetext{
${ }^{178}$ For example, Frederick Corbyn, A Treatise on the Epidemic Cholera as it prevailed in India, Calcutta and London: Baptist Mission Press, Thacker and Co., I832, pp. 21 I-I3.

${ }^{179}$ John G. Malcolmson, 'Letter from India on the Asiatic Cholera', The Lancet, I9, 48I, I7 November 1832, pp. 23I-34.

${ }^{180}$ Lt.-Col. Rowles, On the Propagation of Cholera, Cheltenham: Cunningham and Co., I83i.

${ }^{181}$ Robert Strange, 'Observations on the Cholera Morbus of India', The Lancet, I6, 4 I6, 20 August 1831, p. 648.
} 
Conclusion

The cholera epidemics of $18 \mathrm{I} 7-2 \mathrm{I}$ have few, if any, parallels in the history of the Indian subcontinent. Outbreaks of fever and plague periodically killed large numbers in certain localities, but none appear to have engulfed the entire country or left such devastation in their wake. In view of cholera's ferocity, one might expect that the colonial authorities would have taken drastic action to halt the progress of such an epidemic, but the official reaction confounds our expectations. The poor and impoverished were not stigmatized or regarded as threats, as they so often were in later epidemics. Coercive forms of intervention such as quarantines and confinement were conspicuous by their absence. Frugal paternalism was the order of the day. This rather muted response owed something to the novelty of cholera, but it did not take long for the disease to become naturalized. Even then, most British officials did not see cholera as akin to plague, but rather to famine and the epidemics of fever that often accompanied it. All seemed to proceed from unusual meteorological conditions and were accordingly designated as beyond administrative control. The initial reaction of the government was therefore to provide relief, as it had recently begun to do in the case of famine: a fatalistic attitude which reflected an orientalist conception of India and the Company's stewardship of its domain. This line of thinking was reinforced by the lack of any serious challenge to the Company's authority. Although the disease had a devastating impact on many communities, Indian responses aimed to restore order and unity rather than to challenge British rule. Indeed, there is little evidence to suggest that cholera was attributed to the British or other foreigners.

Community reactions to cholera in India therefore differed greatly from those that followed the arrival of the disease in Europe in the r83os. The chief reason for this was the way in which the crisis was handled by the authorities. European states immediately implemented coercive measures and dealt with cholera in the same manner in which they were accustomed to dealing with plague, eliciting a violent counter-reaction from those who felt they had been unfairly blamed for the disease. ${ }^{182}$ As cholera was seen as a 'natural' disaster by the authorities in India, the question of preventive intervention did not

${ }^{182}$ Baldwin, Contagion and the State in Europe, pp. 37-122; Evans, 'Epidemics and Revolutions'. 
immediately arise. Indeed, the Company's ameliorative response may have served to calm - and certainly did nothing to inflame - the situation. But there may have been another reason for the contrasting reactions of communities in Europe and India. Comparing events in both contexts, one is reminded of Durkheim's observations on the forms of cohesion typical of pre-modern and modern societies. ${ }^{183}$ The former tended to reaffirm community ties spontaneously through religious observance or exemplary punishment, and such motives may be observed during the cholera epidemics in India, in both religious rites and the 'witch' killings of the northern Konkan. Social responses to cholera in Europe were usually animated by different concerns. There was little or no scapegoating, but a good deal of protest against overweening states and their medical representatives. If anyone or anything was suspected of spreading the disease, it was doctors or agents of the state rather than some unfortunate 'sorceress'. ${ }^{184}$ In Western societies, cholera tended to inflame hierarchical (class) divisions rather than stoke intra-community tensions. Governments therefore found it difficult to fashion a response to cholera that was perceived as socially just. In the longer term, however, most European states retreated from confrontation and the common threat posed by infectious disease eventually served to promote social integration. ${ }^{185}$

The question therefore arises as to whether these different dynamics can be understood using Rosenberg's model. When discussing how societies 'manage randomness' - in other words, how they account for the occurrence of epidemics and patterns of mortality within themRosenberg acknowledges that there were great differences between pre-modern and modern societies, noting the gradual ascendency of secular explanations. His model also allows for the coexistence of various forms of collective action. In both respects, his insights help us to make sense of cholera in colonial India, particularly his observations concerning the ritualistic aspects of collective action and their role in community cohesion. ${ }^{186}$ Where his model fails somewhat is in the characterization of these actions as 'public negotiation'. One can see some examples of this - for instance, in the accommodation made

\footnotetext{
${ }^{183}$ Emile Durkheim, The Division of Labor in Society, (trans.) W. D. Halls, New York: Free Press, I997.

${ }^{184}$ Hamlin, Cholera, pp. 8I-83.

${ }^{185}$ See Abram de Swaan, In Care of the State: Health Care, Education and Welfare in Europe in the Modern Era, Cambridge: Polity, I988.

${ }^{186}$ Rosenberg, 'What is an Epidemic?', pp. 282-84.
} 
between the colonial authorities and priests in Madras - but the lack of a common discursive space marks a considerable difference from many European countries and even from India by the end of the century. Additionally, India's diverse populations experienced the epidemics in comparative isolation, there being little to suggest that the events of I8I7-2I - or even epidemics in particular years - were experienced as a unified whole. There was uncertainty about their beginning and end, and they did not exhibit a 'predictable narrative sequence' as in Rosenberg's model. ${ }^{187}$ This remained the case in India until the middle of the nineteenth century, when vital statistics began to be collected for the Indian population. Telegraphic reporting also gave news of outbreaks an immediacy they had hitherto lacked, allowing epidemics to be tracked in something approaching real time. It was only at this point that epidemics became well-defined entities occupying a fairly precise location in space and time. ${ }^{188}$

The amorphousness of epidemics in the early nineteenth century may partially explain why the Company did not react to cholera in a similar way to European states. The latter had some capacity for tracking the movement of disease and counting numbers of dead. However, the Company's actions resemble more closely those of oriental polities, not only those that had previously existed in India but also the Ottoman empire, in which epidemics were seen as partly divinely ordained and partly as products of the environment. The Ottomans considered the European expedient of quarantine to be both unnecessary and inhumane. ${ }^{189}$ The similarities between the Company's responses and those of the Ottomans were not lost on either its critics nor those in Britain who were opposed to quarantine. Indeed, some of the latter wrote approvingly of the measures taken by both the Company and the Ottoman authorities. ${ }^{190}$ But the Company's officials soon began to think differently about cholera and how to respond to it. In some urban centres, the disease came to be seen as a man-made problem demanding a preventive-rather than simply an ameliorative - response.

${ }^{187}$ Ibid., p. 28I.

${ }^{188}$ Mark Harrison, 'Pandemics', in M. Jackson (ed.), The Routledge History of Disease, London: Routledge, 2016, pp. 129-45.

${ }^{189}$ Yaron Ayalon, Natural Disasters in the Ottoman Empire: Plague, Famine, and other Misfortunes, Cambridge: Cambridge University Press, I99I, p. 85.

${ }^{190}$ Charles Maclean, Evils of Quarantine Lawes, and Non-Existence of Pestilential Contagion; deduced from the Phaenomena of the Plague of the Levant, the Yellow Fever of Spain, and the Cholera Morbus of Asia, London: T. G. Underwood, I824, pp. I-38. 
Cholera did not force this change, but it was appropriated by those pushing for urban reform, whether on grounds of health or for commercial, financial, and aesthetic reasons. This occurred first in Calcutta, where the epidemic of 1817 invited unflattering comparisons with other oriental cities and moved the newly formed Lottery Committee to give greater priority to matters of health. After the appearance of cholera, nearly all applications to the Committee - not to mention the Committee's applications to the government - were framed in sanitary terms. So pervasive did these arguments become that the Committee and the government were compelled to consult medical opinion in order to determine the 'degree of danger' posed by nuisances to health. Though hesitant, these moves established a place for medical expertise within the machinery of government and it subsequently became influential in determining the pace and direction of government growth. ${ }^{191}$

The response evident in Calcutta in I817-2I later became visible in other urban centres, such as Madras. But in much of British India, cholera continued to be seen as a natural disaster, requiring little or no intervention on the part of the authorities. It was not until the I83os, and in some cases much later, that the disease came to be associated strongly with insanitary conditions. ${ }^{192}$ By this time, cholera had reached Britain and other European countries, but most Anglo-Indian reports were initially ignored because of their incompatibility with official policy, modelled as it was on the suppression of plague. This shows that the emergence of what C. A. Bayly has termed 'global uniformities' could be a gradual and contested process, knowledge being filtered in the light of political concerns. ${ }^{193}$ It was only after quarantine had failed to contain cholera that Anglo-Indian writings began to be more widely known. As most rejected the theory that cholera was contagious, these works were welcomed by opponents of quarantine and a consensus began to form around its links to sanitary conditions. It was an idea that harmonized with political and economic requirements in Britain and India, and later in other countries. But the nature of cholera's relationship to sanitary conditions remained unclear, opinion being

${ }^{191}$ Harrison, Public Health. On expertise and government more generally, see R. M. MacLeod (ed.), Specialists, Administrators and Professionals 1860-19I9, Cambridge: Cambridge University Press, I988.

${ }^{192}$ As noted for Madras: see Zeheter, Epidemics, Empire, and Environments, Chapters I and 4 .

${ }^{193}$ C. A. Bayly, The Birth of the Modern World I780-I9I4, Oxford: Blackwell, 2004. 
finely balanced between what Hamlin has termed the 'cholera-filth equation' and the 'cholera-poverty equation', ${ }^{194}$ the crucial distinction being that filth was regarded as an 'exciting' or 'necessary' cause and poverty usually a 'predisposing' one. As the predisposing causes of disease were many and various, few entertained the notion that the government - either in India or Britain - had a duty to relieve them. Some medical officers with Indian experience made gestures in this direction, but the only form of preventive intervention that was advocated consistently was sanitary reform - which harmonized with a variety of local concerns - or quarantine in the case of the minority who were contagionists. However, the Company saw its responsibilities with regard to disease as limited, being confined to medical relief and occasional intervention to assist local bodies such as the Lottery Committee. In the coming years, this would change as utilitarian doctrines and evangelical zeal combined to produce a reforming outlook. But in the I8Ios and I820s, the Company was content to manage its Indian estate in a conservative manner, tending to tolerate and even to nurture what it regarded as traditional sources of authority.

${ }^{194}$ Hamlin, Cholera, pp. 78-79. See also Michael Brown, 'From Foetid Air to Filth: The Cultural Transformation of British Epidemiological Thought, ca. 1780-1848', Bulletin of the History of Medicine, 8, 2008, pp. 515-44. 